\title{
1 Paradigmatics and the Declension of Nouns
}

The main focus in this noun description is the paradigm of the noun as well as its case and gender. These issues have been selected first and foremost because the paradigm of the declinable parts of speech of the Latvian language has been insufficiently revealed in theoretical overviews that refer in particular to the structure of parts of speech and the range of the means used to express the grammatical meaning in their paradigms. The noun paradigm is directly connected with the number of cases and the interpretation of their functions in Latvian. Secondly, these issues also have been selected because the Latvian system of noun cases is markedly polyfunctional which means that, alongside the syncretism of endings, noun cases also display curious tendencies of syntactical use and semantic structure that accordingly deserves a more detailed analysis. Thirdly, the use of noun genders is also polyfunctional in Latvian, so they can display various asymmetric uses of noun form and content. In order to make the noun paradigm as well as the case and gender function analysis more explicit, the paradigm of all six declensions is presented in Section 1.2.

\subsection{Introductory Remarks on Paradigmatics}

The basis of any morphological paradigm is a set of forms linked through formal and semantic opposition, for example, the paradigm of the seven, grammatically distinct noun cases in Latvian (nominative, genitive, dative, accusative, instrumental, locative, and vocative, see in detail Section 1.2) and the paradigm of the six grammatically marked verb tense forms (present indefinite, past indefinite, future indefinite, present perfect, past perfect, and future perfect - in detail see Chapter 2), etc.

It is considered that the aforementioned paradigms are the centre of the morphological paradigm structure. The periphery of the morphological paradigm structure is formed by various deviations from the aforementioned principle, i.e., syncretism, merging, or the lack of paradigm elements.

Thus, it can be considered that there are two basic morphological paradigm types:

1. full or complete paradigms;

2. incomplete or defective paradigms.

Both the full and the incomplete paradigms display the following two variations:

1. as mixed or heteroclitic paradigms;

2. as homonymic or syncretic paradigms.

These two types of paradigms tend to combine with other features, such as, for instance, they can be mixed and syncretic. Also, the incomplete paradigms can be mixed and syncretic, etc. 
For example, the full paradigm of the noun that simultaneously is also syncretic, cf. endings - $a s,-u$, and $-\bar{a} m$ :

Table 1.1: The paradigm of the noun māsa 'sister' (F) (adapted from Kalnača 2013a, 54-55)

\begin{tabular}{|c|c|c|}
\hline & SG & PL \\
\hline NOM & $m a \bar{s}-a$ & $m a ̄ s-a s$ \\
\hline GEN & $m a \bar{s}-a s$ & $m a ̄ s-u$ \\
\hline DAT & $m a ̄ s-a i$ & $m a \bar{s}-\bar{a} m$ \\
\hline ACC & $m a ̄ s-u$ & $m a \bar{s}-a s$ \\
\hline INS & (ar) mās-u & (ar) $m \bar{a} s-\bar{a} m$ \\
\hline LOC & $m a \bar{s}-\bar{a}$ & $m a \bar{s}-\bar{a} s$ \\
\hline voc & $m \bar{a} s-ø !$ & mās-as! \\
\hline
\end{tabular}

In Latvian, incomplete and simultaneously syncretic paradigms are, for example, displayed by reflexive nouns that display only two morphologically different forms with the endings $-\bar{a} s$ or -os (see Section 1.4 for reflexive nouns in detail), see Table 1.2:

Table 1.2: The paradigm of the reflexive noun atgriešanās 'returning' (F) (adapted from Kalnača 2013a, 56)

\begin{tabular}{lll}
\hline & SG & PL \\
\hline NOM & atgriešan-ās & atgriešan-ās \\
GEN & atgriešan-āss & atgriešan-os \\
DAT & - & - \\
ACC & atgriešan-os & atgriešan-ās \\
INS & (ar) atgriešan-os & - \\
LOC & - & - \\
VOC & atgriešan-ās! & atgriešan-ās! \\
\hline
\end{tabular}

Adjectives in Latvian are the only example of the mixed and simultaneously syncretic paradigm. This paradigm is formed with the help of the suffix $-\bar{e} j-$. In the dative and locative cases it is used with the definite endings in both numbers as well as in the plural instrumental case, thereby resulting in definite forms that are identical to the indefinite adjectival forms: 
Table 1.3: The paradigm of the definite adjective pēdējais 'last’ (M) (adapted from Kalnača 2013a, 63)

\begin{tabular}{|c|c|c|}
\hline & SG & PL \\
\hline NOM & pēdèj-ais & pēdēj-ie \\
\hline GEN & pēdēj-ā & pēdēj-o \\
\hline DAT & $\begin{array}{l}\text { pēdèj-am } \\
\left({ }^{\star} p \bar{p} \overline{d e} j-a j a m\right)\end{array}$ & $\begin{array}{l}\text { pēdēj-iem } \\
\text { (" }{ }^{\star} \text { ēdēj-ajiem) }\end{array}$ \\
\hline ACC & pēdēj-o & pēdēj-os \\
\hline INS & (ar) pēêejj-o & $\begin{array}{l}\text { (ar) pēdēj-iem } \\
\text { ("pēéej-ajiem) }\end{array}$ \\
\hline LOC & $\begin{array}{l}p \bar{e} d \bar{e} j-\bar{a} \\
\left({ }^{*} p \bar{e} d \bar{e} j-a j \bar{a}\right)\end{array}$ & $\begin{array}{l}\text { pēdēj-os } \\
\text { ("pēdéj-ajos) }\end{array}$ \\
\hline VOC & pēdèj-ais! / pēdēj-o! & pēdēj-ie! \\
\hline
\end{tabular}

The mixed paradigms in this case might be considered as an alternative for the incomplete paradigms in order to avoid difficult to pronounce sound clusters in the combinations of morphemes: the forms marked with the asterisk in Table 1.3 are not considered euphonic in the Latvian literary language and are replaced by the forms of indefinite adjectives (see also Blinkena 2002, 158-159).

As can be seen in the examples, both paradigm types as well as their variants are found in Latvian. Certainly, full paradigms are the most frequent: the noun (also adjective, numeral, and declinable participle) system of seven cases, the system of finite verb forms with three singular and three plural persons in all forms, etc. The language system is based on the full paradigms. In addition, they serve as a departure point for the incomplete and other paradigm type recording. However, in Standard Latvian due to the phonetic and morphological changes of the endings as well as due to the different processes of analogy and other historical processes, morphological paradigms of nominals (also pronominals and verbs) display syncretism, i.e., homoforms of grammatical forms (see Sections 1.2 and 1.3 for noun forms in detail).

Haspelmath (2002, 143-144) considers that the combination of various grammatical forms into one paradigm belongs to the periphery of morphological structure, for example the combination of synthetic and analytical forms in the verb tense category in German, English, and other languages, in which the indefinite tense forms are synthetic, whereas perfect tense forms are analytic. The same refers to the Latvian tense paradigm that combines synthetic and analytic forms: 
Table 1.4: The paradigm of verb (indicative mood) lasit 'to read'

\begin{tabular}{|c|c|c|}
\hline & Indefinite tense form & Perfect tense form \\
\hline PRS & lasu 'I read' & esmu lasījis (M), -usi (F) 'I have read' \\
\hline PST & lasiju 'I read' & biju lasijijs, -usi 'I had read’ \\
\hline FUT & lasišu 'I will read' & $\begin{array}{l}\text { būšu lasījis, -usi } \\
\text { 'I will have read' }\end{array}$ \\
\hline
\end{tabular}

In this regard, it is also relevant to view the instrumental as the only analytic noun form included in the Latvian case paradigm. There are historical reasons for this phenomenon: the historical development of case endings towards homonymy that has required the use of the preposition $a r$ 'with' for the comprehensive formal distinction of the singular instrumental and accusative or the plural instrumental and dative. For example, see Table 1.1, which shows the declensional paradigm of māsa 'sister' declension (see Kalnača 1999; Grīsle 2007, and Section 1.3.1 for more detail).

Morphological paradigm typology also reveals a close link on the boundary between morphology and syntax. First of all, it refers to the merging of synthetic and analytic forms into one paradigm. The structure of an analytic form usually is periphrastic; it is the combination of several word groups that are of different syntactic status, i.e., the combination of an independent word and an auxiliary word (see also Matthews 1997, 17). In the system of verb forms, periphrasis is the combination of an auxiliary verb and a declinable past participle combination, whereas in the noun system it is a combination of a preposition and a noun. In relation to verbs, historically the dominance of the Latin language tradition has determined the embedding of periphrastic word forms into the morphological paradigm of tenses, whereas this is less evident in similar noun forms (see in detail Kalnača 2000b).

Interaction of morphology and syntax in the paradigmatics of grammatical forms is observable if there is unification of incomplete and syncretic paradigms due to syntactic use. In Latvian, reflexive nouns are vivid examples of this phenomenon (see Section 1.4 for a detailed discussion).

\subsection{Declension}

The Latvian noun declension system represents a typical Indo-European seven case system (nominative, genitive, dative, accusative, instrumental, locative, vocative) with six declensions, two numbers, and two genders (see for example Endzelīns 1951; Ahero et al. 1959; Paegle 2003).

As was mentioned in Section 1.1, full or complete paradigms dominate the declension system for nouns containing some syncretic forms; however, there are also incomplete syncretic paradigms of reflexive nouns, which have been considered 
in detail in Section 1.4. Beyond the declension system there are nondeclinable nouns as well as nouns used only in one form - the genitive in singular or plural (see further in the present chapter).

The noun declensions are distinguished on the basis of the different endings in the case and number paradigms and partly on the basis of gender (Kalme, Smiltniece 2001, 101; Paegle 2003, 45; Nau 2011). The traditional system for distinguishing declensions in Latvian is as follows (Kalme, Smiltniece 2001, 101-112, regarding the development and changes of the declension system see Smiltniece 2002, 44-53; Paegle 2003, 45-47):

1. tèvs 'father' (M)

cel̦š 'road, path' (M)

2. brālis 'brother' (M)

akmens 'stone' (M) (subgroup of consonantal stem nouns, represented by the words akmens 'stone', asmens 'blade', ūdens 'water', rudens 'autumn', zibens 'lightning', mēness 'moon', and partially also suns 'dog')

3. lietus 'rain' (M)

4. māsa 'sister' (F)

puika 'boy' (M)

5. māte 'mother' (F)

6. zivs 'fish' (F)

ḷaudis 'people' (M) (pluralia tantum)

The six declension paradigm system of the Latvian language is as follows Table 1.5.

In the declensions comprising both genders, the difference between the genders is seen in the singular dative form, for example in the singular dative form of the 4th declension (Paegle 2003, 32, 50):

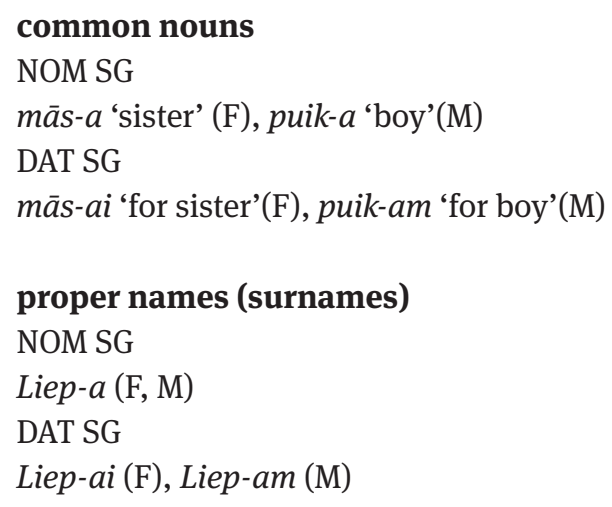


Table 1.5: The paradigms of the Latvian noun declensions (adapted from Kalnača 2013a, 54-55)

\begin{tabular}{|c|c|c|c|c|c|c|}
\hline SG & & & Declension & & & \\
\hline Case & $1(M)$ & $2(M)$ & $3(M)$ & $4(F, M)$ & $5(F)$ & $6(F)$ \\
\hline NOM & $\begin{array}{l}t e \bar{e} v-s, \\
c e l,-s ̌\end{array}$ & $\begin{array}{l}\text { brāl-is, } \\
\text { akmen-s }\end{array}$ & liet-us & $\begin{array}{l}\text { mās-a, } \\
\text { puik-a }\end{array}$ & māt-e, & $z i v-s$ \\
\hline GEN & $\begin{array}{l}\text { tēv-a, } \\
\text { cel!-a }\end{array}$ & $\begin{array}{l}\text { brāl-a, } \\
\text { akmen-s }\end{array}$ & liet-us & $\begin{array}{l}\text { mās-as, } \\
\text { puik-as }\end{array}$ & māt-es, & ziv-s \\
\hline DAT & $\begin{array}{l}\text { tēv-am, } \\
\text { cel!-am }\end{array}$ & $\begin{array}{l}\text { brāl-im, } \\
\text { akmen-im }\end{array}$ & liet-um & $\begin{array}{l}\text { mās-ai, } \\
\text { puik-am }\end{array}$ & māt-ei & $z i v-i j$ \\
\hline ACC & $\begin{array}{l}t e \bar{v}-u, \\
\text { cell-u }\end{array}$ & $\begin{array}{l}\text { brāl-i, } \\
\text { akmen-i }\end{array}$ & liet-u & $\begin{array}{l}\text { mās-u, } \\
\text { puik-u }\end{array}$ & $m a \bar{t}-i$ & $z i v-i$ \\
\hline INS & $\begin{array}{l}\text { (ar) têv-u, } \\
\text { (ar) cell-u }\end{array}$ & $\begin{array}{l}\text { (ar) brāl-i, } \\
\text { (ar) } \\
\text { akmen-i }\end{array}$ & (ar) liet-u & $\begin{array}{l}\text { (ar)mās-u, (ar) } \\
\text { puik-u }\end{array}$ & (ar) māt-i & (ar) ziv-i \\
\hline LOC & $\begin{array}{l}t \bar{e} v-\bar{a} \\
\text { cel-āa }\end{array}$ & $\begin{array}{l}\text { brāl-ī, } \\
\text { akmen-ī }\end{array}$ & liet- $\bar{u}$ & $\begin{array}{l}\text { mās-ā, } \\
\text { puik- } \bar{a}\end{array}$ & $m a \bar{t} t-\bar{e}$ & $z i v-\bar{I}$ \\
\hline VOC & $\begin{array}{l}t \bar{e} v-\varnothing ! \\
t \bar{e} v-s ! \\
c e l-s ̌ s !\end{array}$ & $\begin{array}{l}\text { brāl-i!, } \\
\text { akmen-s! }\end{array}$ & liet-u! & $\begin{array}{l}\text { mās-ø!, } \\
\text { mās-a!, } \\
\text { puik-a! }\end{array}$ & $\begin{array}{l}\text { māt-ø!, } \\
\text { māt-e! }\end{array}$ & ziv-s! \\
\hline PL & & & & & & $(F, M)$ \\
\hline NOM & $\begin{array}{l}t \bar{e} v-i, \\
c e l,-i\end{array}$ & $\begin{array}{l}\text { brāl-i, } \\
\text { akmen, }-i\end{array}$ & liet $-i$ & $\begin{array}{l}\text { mās-as, } \\
\text { puik-as }\end{array}$ & māt-es & $\begin{array}{l}\text { ziv-is, } \\
\text { laud-is }\end{array}$ \\
\hline GEN & $\begin{array}{l}t \bar{e} v-u \\
c e l,-u\end{array}$ & $\begin{array}{l}\text { brāḷ-u, } \\
\text { akmen, } u\end{array}$ & liet-u & $\begin{array}{l}\text { mās-u, } \\
\text { puik-u }\end{array}$ & $m a \bar{a} \check{-}-u$ & $\begin{array}{l}\text { zivj-u, } \\
\text { l̦auž-u }\end{array}$ \\
\hline DAT & $\begin{array}{l}\text { tēv-iem, } \\
\text { cell-iem }\end{array}$ & $\begin{array}{l}\text { brāl-iem, } \\
\text { akment-iem }\end{array}$ & liet-iem & $\begin{array}{l}\text { mās-ām, puik- } \\
\bar{a} m\end{array}$ & $m a \bar{t}-\bar{e} m$ & $\begin{array}{l}\text { ziv-īm, } \\
\text { ḷaud-īm }\end{array}$ \\
\hline ACC & $\begin{array}{l}\text { tēv-us, } \\
\text { cel-us }\end{array}$ & $\begin{array}{l}\text { brāl-us, } \\
\text { akmeñ-us }\end{array}$ & liet-us & $\begin{array}{l}\text { mās-as, } \\
\text { puik-as }\end{array}$ & māt-es & $\begin{array}{l}\text { ziv-is, } \\
\text { laud-is }\end{array}$ \\
\hline INS & $\begin{array}{l}\text { (ar) } \\
\text { tēv-iem, } \\
\text { (ar) } \\
\text { ceḷ-iem }\end{array}$ & $\begin{array}{l}\text { (ar) } \\
\text { bräl-iem, } \\
\text { (ar) } \\
\text { akmeñ-iem }\end{array}$ & $\begin{array}{l}\text { (ar) } \\
\text { liet-iem }\end{array}$ & $\begin{array}{l}\text { (ar) } \\
\text { mās-ām, } \\
\text { (ar) } \\
\text { puik-ām }\end{array}$ & $\begin{array}{l}\text { (ar) } \\
m \bar{a} t-\bar{e} m\end{array}$ & $\begin{array}{l}\text { (ar) ziv-īm, (ar) } \\
\text { ḷaud-īm }\end{array}$ \\
\hline LOC & $\begin{array}{l}\text { tēv-os, } \\
\text { celt-os }\end{array}$ & $\begin{array}{l}\text { brāl-os, } \\
\text { akmeñ-os }\end{array}$ & liet-os & $\begin{array}{l}\text { mās-ās, } \\
\text { puik-ās }\end{array}$ & māt-ēs & $\begin{array}{l}\text { ziv-īs, } \\
\text { ḷaud-īs }\end{array}$ \\
\hline VOC & $\begin{array}{l}\text { tēv-i!, } \\
\text { cel-i! }\end{array}$ & $\begin{array}{l}\text { brāl-il, } \\
\text { akmen, }-i !\end{array}$ & liet-i! & $\begin{array}{l}\text { mās-as!, puik- } \\
\text { as! }\end{array}$ & māt-es! & $\begin{array}{l}\text { ziv-is!, } \\
\text { l̦aud-is! }\end{array}$ \\
\hline
\end{tabular}


This method also works in the masculine singular dative form of the 5 th declension, as seen in the following surnames:

$$
\begin{aligned}
& \text { Egl-e, Pried-e, Niedr-e (F, M) } \\
& \text { Egl-ei, Pried-ei, Niedr-ei (F) } \\
& \text { Egl-em, Pried-em, Niedr-em (M) }
\end{aligned}
$$

In Latvian there are also different masculine and feminine singular dative forms of common gender nouns in the 4th and 5th declension (see Section 1.6 for a detailed discussion), for example:

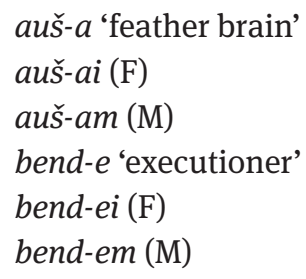

Thus, it is possible to propose the following system of case and number endings for nouns. Note that the endings preceded by palatalization have been displayed as separate exponents (read below in the present chapter about this morphological process; see also Haspelmath 2002, 242):

\section{Singular}

The 2nd declension is divided into two subgroups - 2b (consonantal stem nouns), $2 \mathrm{a}$ (all other nouns).

The 5th declension also includes the ending -em for masculine surnames and common gender nouns such as bende 'executioner', if they are used in the masculine gender, see examples (1.2)-(1.4)).

With respect to the analysis of the interrelation of grammatical form frequency and the differentiation of exponents (i.e., different endings), Haspelmath (2002, 238239) points out that inflecting languages generally display the following grammatical form frequency (only the characteristics referring to nouns are mentioned): for number: singular $>$ plural $>$ dual, for case: nominative $>$ accusative $>$ dative $(>$ represents 'is used more frequently than'). The interrelation of frequency and exponent differentiation fully works in Latvian, if the number of endings in singular and plural is compared. Singular, obviously as a more frequently used grammatical form, displays a greater variety of case endings, which is confirmed by the number of exponents, and a smaller number of syncretic forms than in plural (see also Nau 2011). Plural, in relation to case endings, is considerably more unified: the number of syncretic forms is greater; for example, the forms of plural nominative, accusative, and vocative fully coincide in the 4th, 5 th, and 6 th declensions. Moreover, in Latvian 
there is only one ending - $u$ in all declensions for plural genitive with only one variant $--^{\prime} u$ in the 2nd declension.

However, the second regularity mentioned by Haspelmath referring to the interrelation of the number of exponents and the frequency of case use is not confirmed in Latvian. According to Haspelmath, the greatest number of exponents should be in nominative, then fewer in accusative, and least of all in dative. Latvian displays a different sequence: dative, vocative $>$ nominative $>$ accusative. The overview of the Latvian declension system presented in Tables 1.6 and 1.7 shows that generally the greatest number of exponents (i.e., different endings) are in the dative and also the vocative: seven in singular and five in plural, which means twelve in total (for a discussion regarding the number of exponents in singular dative see also Nau 2011, 146). The variety of endings in the dative has encouraged some linguists to accept the dative as the basis for distinguishing the Latvian noun declension from each other (for example, Bērziņa 1942, 62; Nītina 2001, 15-19; Holst 2001; also, Nau 2011, 152).

Nominative, which traditionally has been considered the case distinguisher across declensions in Latvian, displays a smaller number of exponents: eleven different endings (six in singular, five in plural). In addition, the 1st and 6th declensions have the syncretic ending -s in singular nominative (see Table 1.5: têvs-s 'father' and $z i v$-s

Table 1.6: Singular case endings

\begin{tabular}{|c|c|c|c|c|c|c|c|c|}
\hline \multirow{2}{*}{ Case } & \multicolumn{7}{|c|}{ Declension } & \multirow{2}{*}{$\begin{array}{l}\text { Number of } \\
\text { exponents }\end{array}$} \\
\hline & 1 & 3 & 6 & $2 b$ & $2 a$ & 4 & 6 & \\
\hline NOM & $-S,-\check{S}$ & -us & & & -is & $-a$ & $-e$ & 6 \\
\hline VOC & $-\varnothing,-s,-\check{s}$ & $-u$ & $-s$ & & $-i$ & $-\varnothing,-a$ & $-\varnothing,-e$ & 7 \\
\hline GEN & $-a$ & - us & & & $-' a$ & -as & -es & 6 \\
\hline ACC & $-u$ & & $-i$ & & & $-u$ & $-i$ & 2 \\
\hline INS & & & & & & $-u$ & -1 & 2 \\
\hline DAT & $-a m$ & $-u m$ & $-i j$ & $-i m$ & & $-a i,-a m$ & -ei, -em & 7 \\
\hline LOC & $-\bar{a}$ & $-\bar{u}$ & $-\bar{\imath}$ & & & $-\bar{a}$ & $-\bar{e}$ & 4 \\
\hline
\end{tabular}

Table 1.7: Plural case endings

Plural

\begin{tabular}{|c|c|c|c|c|c|c|c|}
\hline \multirow{2}{*}{ Case } & \multicolumn{6}{|c|}{ Declension } & \multirow{2}{*}{$\begin{array}{l}\text { Number of } \\
\text { exponents }\end{array}$} \\
\hline & 2 & 1 & 3 & 4 & 5 & 6 & \\
\hline NOM & $-i i$ & \multirow{2}{*}{\multicolumn{2}{|c|}{$-i$}} & \multirow{2}{*}{$-a s$} & \multirow{2}{*}{-es } & \multirow{2}{*}{-is } & 5 \\
\hline VOC & & & & & & & 5 \\
\hline GEN & $-‘ u$ & $-u$ & & & $-{ }^{\prime} u,-u$ & & 2 \\
\hline $\mathrm{ACC}$ & -'us & $-u s$ & & -as & -es & -is & 5 \\
\hline INS & \multirow{2}{*}{ - ‘iem } & \multirow{2}{*}{-iem } & & $-\bar{a} m$ & \multirow{2}{*}{$-\bar{e} m$} & \multirow{2}{*}{$-i \bar{m}$} & 5 \\
\hline DAT & & & & & & & 5 \\
\hline LOC & - 'os & $-O S$ & & $-\bar{a} s$ & $-\bar{e} s$ & $-\bar{I} S$ & 5 \\
\hline
\end{tabular}


'fish' and Table 1.6). The plural nominative endings are also the same in the 1st, 2nd, and 3rd declensions (see Table 5: tē $v$ - $i$ 'fathers', brāl-i 'brothers', liet-i 'rains').

However, the accusative (like the instrumental) displays the smallest number of exponents: seven different endings (only two in singular and five in plural), which, however, does not mean that the accusative is infrequently used in Latvian. On the contrary, as the opposition of transitive/intransitive verbs is well developed in Latvian (see Chapter 6 about this opposition), the accusative, therefore, is one of the most important cases for sentence structure.

Surprisingly, the vocative displays a comparatively large number of exponents, twelve, and as many different endings as the dative. The vocative, which is generally considered a peripheral case, in theory would not require the same large number of exponents as seen in, for example, the nominative or accusative cases used as the so-called central cases of a sentence. However, in Latvian alongside morphologically vocative forms, it is possible to use nominative forms (see Section 1.3.2) in the function of vocative. This use of nominative forms has enriched the number of vocative exponents.

As is pointed out by Nau $(2011,152)$, there is no doubt that the dative is a very frequently used form, at least for the nouns denoting human beings. This is determined by the specific functions of the dative in Latvian: to express indirect object as well as the so-called dative subjects, in possessive constructions, in debitive, and other cases (see Section 1.5 regarding the functions of the dative as well as Lokmane, Kalnača 2014). It has to be noted that the vocative is also frequently used in Latvian. It is the most frequent case in spoken language as well as in business texts. The vocative is widely used, for example, in various business letters, invitations, and similar business texts (Skujiṇa 1999, 51-55).

\subsubsection{Noun Forms and Palatalization}

As shown in Tables 1.5-1.7, palatalization occurs in Latvian noun formation where it marks either the singular or plural genitive (as in the 2nd, 5th, and 6th declensions) or the contrast between the plural paradigm and the singular paradigm (as in the 2nd declension) (Kalnača 2004a, 71-75). Historically $j$ was a suffix which phonetically has blended with the preceeding morpheme (the stem or the lexeme-forming suffix) (Endzelīns 1981, 416-431, 488-494).

Palatalization occurs according to the following morphophonological system. The examples contrast GEN SG or GEN PL forms containing palatalization with NOM SG which they follow.

(1.5) $\mathrm{n}>\mathrm{n} \quad$ zirnis : zirna 'pea'; avene : avenุu 'raspberry'

$1>1, \quad$ ūlis : pūḷa 'crowd'; egle : egḷu 'fir'; pils : piḷu 'castle'

t $>$ š zutis : zuša 'eel'; plits : plišu 'cooker'; telts : telšu 'tent'

$\mathrm{d}>\check{\mathrm{z}} \quad$ briedis : brieža 'deer'; pagalde : pagalžu 'the area under a table'

$\mathrm{s}>$ š lasis : laša 'salmon'; lāse : lāšu 'drop'; tāss : tāšu 'birch-bark' 


$$
\begin{array}{ll}
\mathrm{z}>\check{\mathrm{z}} & \text { nazis : naža 'knife'; vāze : vāžu 'vase' } \\
\mathrm{c}>\text { č } & \text { lācis : lāča 'bear'; svece : sveču 'candle' } \\
\mathrm{dz}>\mathrm{dž} & \text { dadzis : dadža 'thistle'; kaudze : kaudžu 'pile' }
\end{array}
$$

If a word stems ends in consonants $v, m, p, b$ blending occurs:

(1.6) $\quad \mathrm{v}>\mathrm{vj} \quad$ kalvis : kalvja 'blacksmith'; virve : virvju 'rope'; govs : govju 'cow'

$\mathrm{m}>\mathrm{mj}$ kurmis : kurmja 'mole'; vēlme : vēlmju 'desire'

p > pj skapis : skapja 'closet'; kurpe : kurpju 'shoe'

b > bj gulbis : gulbja 'swan'; piekabe : piekabju 'trailer'

The palatalization found in the contrast of NOM SG and GEN SG or GEN PL can also extend to the palatalization of entire consonant clusters:

$$
\begin{aligned}
& \text { sl >šl } \quad \text { pūslis : pūšḷ̆la 'bladder' } \\
& \text { zl > žl zizlis : zižla 'stick' } \\
& \text { sn > šn, ceturksnis : ceturkšn,a 'quarter' } \\
& \text { zn > žn, lauznis : laužņa 'bar'; grieznes : griežņu 'scissors' } \\
& \text { st }>\text { š bārksts : bārkšu 'fringe' }
\end{aligned}
$$

Even if palatalization (see Table 1.5) is observed in the grammatical forms of the 2nd, 5th, and 6th declensions, there are some exceptions that do not display the expected alternation.

1. 2nd declension

a. male personal names -tis, -dis (two syllables)

At-is : At-a 'Atis'

Gunt-is : Gunt- $a$ 'Guntis'

Vald-is : Vald- $a$ 'Valdis'

Ald-is : Ald-a 'Aldis'

but

\section{male personal names of three syllables}

Visvald-is : Visvalž- $a$ 'Visvaldis'

Tālivald-is : Tālivalž- $a$ 'Tālivaldis'

Saulved-is : Saulvež-a 'Saulvedis'

b. some common nouns

viesis : viesa 'guest'

kaķis : kaķa 'cat'

kugís : kuǵa 'ship' 
2. some 5th declension common nouns -ste, -te, -se:

(1.9)

a. kaste : kastu 'box'

aste : astu 'tail'

karaliste : karalistu 'kingdom'

b. mute : mutu 'mouth'

c. kase : kasu 'cash register, till'

pase : pasu 'passport'

3. 6th declension:

(1.10)

a. common nouns

acs : acu 'eye'

uzacs : uzacu 'eyebrow'

auss : ausu 'ear'

balss : balsu 'voice'

debess : debesu 'sky'

valsts : valstu 'state'

vēsts : vēstu 'message'

b. placenames

Cēsis : Cēsu 'Cēsis'

In general it can be concluded that the paradigms of the Latvian noun declension system are unified in terms of stress, syllable tone, and vocalism, and therefore endings are the main indicators of a particular case and the morphological marking of cases in the Latvian language in general occurs only in relation with consonant palatalization (Nau 2011, 173). In the Latvian noun paradigm there is no typical morphophonological marking of the nominative and the dependent cases (see also Nau 2011).

\subsubsection{Nondeclinable nouns}

In Modern Latvian there are also nondeclinable nouns. These nouns are all borrowings (Kalme \& Smiltniece 2001, 113; Kalnača 2013a, 56), for example:

(1.11) eiro 'euro', kino 'cinema', ragū 'ragout', radio 'radio', ateljē 'atelier/tailoring' Tartu 'Tartu', Oslo 'Oslo', Kongo 'Congo', Āzē 'Aasee' 
Nondeclinable common nouns are normally in the masculine gender in Latvian, whereas the gender of nondeclinable proper nouns depends on the gender of the named item and the context in which it is used. Rivers, towns/cities, countries, and islands are in the feminine gender:

(1.12) Po upe 'Po river'

Oslo pilsēta 'Oslo city'

Kongo valsts 'Congo country'

Hījumā sala 'Hiiumaa island'

Lakes, mountains, and villages are in the masculine gender:

(1.13) O ezers Norvēgijā ‘Å lake in Norway’

Kilimandžāro kalns 'Kilimanjaro mountain'

$O$ ciems ' $O$ village'

The gender of nondeclinable personal names depends on the sex of that particular person:

a. names

Aino (F) Kalninga

Bruno (M) Liepiņš

b. surnames

Ilze Megi (F)

Jānis Megi (M)

The category of case and number of these nouns can be determined only in context (Paegle 2002, 53):

\section{(1.15) Tartu (F)}

a. LOC

$\begin{array}{llll}\text { Es } & \text { sestdien } & \text { biju } & \text { Tartu } \\ \text { I } & \text { Saturday } & \text { be.PST.1sG } & \text { Tartu }\end{array}$

'I went to Tartu on Saturday'

b. DAT

Lìdz Tartu braucām apmēram četras stundas

to Tartu drive.PST.1PL about four.ACC.PL.F hour. ACC.PL.F

'It took us about four hours to get to Tartu' 
c. GEN

\begin{tabular}{|c|c|c|c|c|}
\hline Tartu Universitāte & ir & $v e c \bar{k} k a$ & $n e k \bar{a}$ & Latvijas \\
\hline $\begin{array}{l}\text { Tartu university.NOM.F } \\
\text { Universitāte } \\
\text { university.NOM.F }\end{array}$ & be.PRS.3 & older.NOM.F & than & Latvia.GEN.F \\
\hline
\end{tabular}

In colloquial speech the nondeclinable lexemes often get changed to declinable nouns by adding endings and diminutive suffixes:

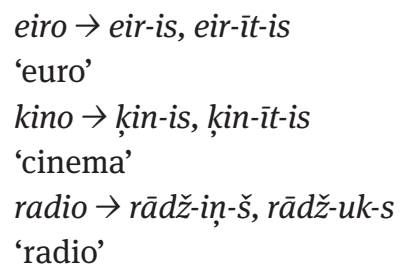

There is also a range of nondeclinable nouns in Standard Latvian that during recent years have changed to declinable nouns through the addition of endings or suffixes (Kalme \& Smiltniece 2001, 113), for example:

baroko, čello, pianīno, mannā, sodā $\rightarrow$

baroks 'baroque', čells 'cello', pianīns 'piano' (all M),

manna 'manna', soda 'soda' (both F)

(1.18) $\quad \check{z} e l e \bar{e}$, filē, dražè, Tokio $\rightarrow$

želeja 'jelly’, fileja ‘fillet', dražeja 'dragee', Tokija ‘Tokyo' (all F)

This group of nondeclinable nouns is composed of genitives - nouns which only have a singular or plural genitive form and are usually used as a modifier (Soida 1976; Kalme \& Smiltniece 2001, 113-114; Paegle 2003, 53-54), for example:
bezsvara stāvoklis 'weightlessness'
divstāvu māja 'two-storey building'
zaļbriedu pupas 'green beans'
augstkalnu gaiss 'high mountain air'

The following two types are distinguished: 
1. compound genitives

(1.20) zempapēžu kurpes 'low-heeled shoes'

zeltspārnu vabole 'golden-winged beetle'

pusaugu zēns 'teenage boy'

2. prepositional genitives

(1.21) pirmskara notikumi 'pre-war events'

bezgaisa telpa 'airless room'

starppilsētu autobuss 'intercity bus'.

\subsection{Case Syncretism}

As is mentioned above in 1.1, a typical feature of Latvian is paradigm syncretism. This syncretism is especially characteristic for noun forms (see noun declension examples in Table 1.5 as well as Table 1.6 for the classification of case endings). The main instances of noun case syncretism in Latvian are as follows:

1. All declensions display syncretism in the accusative and instrumental in singular and in the dative and instrumental in plural:

Table 1.8: Syncretism in the accusative and instrumental

\begin{tabular}{|c|c|c|c|c|c|c|}
\hline SG & & Dec & ension & & & \\
\hline & $1(M)$ & $2(M)$ & $3(M)$ & $4(F, M)$ & $5(F)$ & $6(F)$ \\
\hline ACC & $\begin{array}{l}t \bar{v} v-u \\
c e l-u\end{array}$ & $\begin{array}{l}\text { brāl-i, } \\
\text { akmen-i }\end{array}$ & liet-u & $\begin{array}{l}\text { mās-u, } \\
\text { puik-u }\end{array}$ & $m a ̄ t-i$ & $z i v-i$ \\
\hline INS & $\begin{array}{l}\text { (ar) } t \bar{e} v-u \\
\text { (ar) cel̦-u }\end{array}$ & $\begin{array}{l}\text { (ar) bräl-i, (ar) } \\
\text { akmen-i }\end{array}$ & (ar) liet-u & $\begin{array}{l}\text { (ar) mās-u, } \\
\text { (ar) puik-u }\end{array}$ & (ar) māt-i & (ar) ziv-i \\
\hline PL & & & & & & $(F, M)$ \\
\hline DAT & $\begin{array}{l}\text { tēv-iem, } \\
\text { ceḷ-iem }\end{array}$ & $\begin{array}{l}\text { brāl,-iem, akmeṇ- } \\
\text { iem }\end{array}$ & liet-iem & $\begin{array}{l}\text { mās-ām, } \\
\text { puik-ām }\end{array}$ & māt-ēm & $\begin{array}{l}\text { ziv-īm, } \\
\text { laud-ĩm }\end{array}$ \\
\hline INS & $\begin{array}{l}\text { (ar) } \\
\text { tēv-iem, } \\
\text { (ar) cel!- } \\
\text { iem }\end{array}$ & $\begin{array}{l}\text { (ar) } \\
\text { brāl-iem, } \\
\text { (ar) } \\
\text { akmen-iem }\end{array}$ & (ar) liet-iem & $\begin{array}{l}\text { (ar) } \\
\text { mās-ām, (ar) } \\
\text { puik-ām }\end{array}$ & $\begin{array}{l}\text { (ar) } \\
\text { māt-ēm }\end{array}$ & $\begin{array}{l}\text { (ar) ziv-īm, (ar) } \\
\text { ḷaud-īm }\end{array}$ \\
\hline
\end{tabular}

2. In the 1st, 3rd, and 4th declensions there is syncretism in the singular accusative and instrumental as well as in the plural genitive: 
Table 1.9: Syncretism in the accusative, instrumental, and genitive

\begin{tabular}{|c|c|c|c|}
\hline SG & $1(M)$ & $3(M)$ & 4 (FM) \\
\hline $\mathrm{ACC}$ & $\begin{array}{l}t e \bar{v}-u \\
c e l-u\end{array}$ & liet-u & $\begin{array}{l}\text { mās-u, } \\
\text { puik-u }\end{array}$ \\
\hline INS & $\begin{array}{l}\text { (ar) tèv-u, } \\
\text { (ar) cel̦-u }\end{array}$ & (ar) liet-u & $\begin{array}{l}\text { (ar) mās-u, } \\
\text { (ar) puik-u }\end{array}$ \\
\hline \multicolumn{4}{|l|}{ PL } \\
\hline GEN & $\begin{array}{l}t e \bar{v}-u, \\
c e l-u\end{array}$ & liet-u & $\begin{array}{l}\text { mās-u, } \\
\text { puik-u }\end{array}$ \\
\hline
\end{tabular}

3. In the 4th and 5th declensions there is syncretism in the singular genitive as well as in the plural nominative and accusative. In the 6th declension syncretism is found in the plural nominative and accusative:

Table 1.10: Syncretism in the genitive, nominative, and accusative

\begin{tabular}{llll}
\hline SG & $\mathbf{4}(\mathbf{F}, \mathbf{M})$ & $\mathbf{5}(\mathbf{F})$ & \\
\hline GEN & $\begin{array}{l}\text { mās-as, } \\
\text { puik-as }\end{array}$ & māt-es & \\
PL & mās-as, & & \\
NOM & $\begin{array}{l}\text { puik-as }) \\
\text { mās-as, } \\
\text { puik-as }\end{array}$ & māt-es & ziv-is, laud-is \\
ACC & māt-es & ziv-is, laud-is \\
\hline
\end{tabular}

4. The 1st, 4th, 5th, and 6th declensions as well as the 2nd declension subgroup of consonantal stems partly coincide in the singular nominative and vocative. All declensions fully coincide in the plural nominative and vocative.

Table 1.11: Syncretism in the nominative and vocative

\begin{tabular}{|c|c|c|c|c|c|c|}
\hline \multirow[t]{2}{*}{ SG } & \multicolumn{4}{|c|}{ Declension } & \multirow[b]{2}{*}{$5(F)$} & \multirow[b]{2}{*}{$6(F)$} \\
\hline & $1(M)$ & $2(M)$ & $3(M)$ & $4(F, M)$ & & \\
\hline NOM & $\begin{array}{l}t \bar{e} v-s, \\
c e l \underline{-} \text { š }\end{array}$ & akmen-s & & $\begin{array}{l}\text { mās-a, } \\
\text { puik-a }\end{array}$ & $m a \bar{t}-e$ & ziv-s \\
\hline VOC & $\begin{array}{l}t \bar{e} v-\varnothing !, t \bar{e} v-s ! \\
\text { cel!-š! }\end{array}$ & akmen-s! & & $\begin{array}{l}\text { mās-ø!, mās-a!, } \\
\text { puik-a! }\end{array}$ & $\begin{array}{l}\text { māt-ø!, } \\
\text { māt-e! }\end{array}$ & ziv-s! \\
\hline PL & & & & & & M) \\
\hline NOM & $\begin{array}{l}t \bar{e} v-i \\
c e l+-i\end{array}$ & $\begin{array}{l}\text { brāl-i, } \\
\text { akment-i }\end{array}$ & liet- $i$ & $\begin{array}{l}\text { mās-as, } \\
\text { puik-as }\end{array}$ & māt-es & $\begin{array}{l}\text { ziv-is, } \\
\text { laud-is }\end{array}$ \\
\hline VOC & $\begin{array}{l}t \bar{e} v-i ! \\
\text { cel-i! }\end{array}$ & brāḷ-i!, akmeṇ-i! & liet-i! & $\begin{array}{l}\text { mās-as!, puik- } \\
\text { as! }\end{array}$ & māt-es! & $\begin{array}{l}\text { ziv-is!, } \\
\text { laud-is! }\end{array}$ \\
\hline
\end{tabular}


5. The singular accusative and vocative forms of the 2nd declension (with the exception of the subgroup of consonantal nouns) and 3rd declension are syncretic. In addition, the 2 nd declension nominative singular is syncretic (note that the end of the noun stem is marked by palatalization), while the 3rd declension genitive plural is also syncretic.

Table 1.12: Syncretism in the accusative, vocative, nominative, and genitive

\begin{tabular}{lcc}
\hline SG & $2(\mathrm{M})$ & $3(\mathrm{M})$ \\
\hline ACC & brāl-i & liet-u \\
VOC & brāl-i! & liet-u! \\
PL & & \\
NOM & brāl-i & \\
GEN & & liet-u \\
\hline
\end{tabular}

6. The 2nd declension subgroup of consonantal stem nouns and 3rd and 6th declension nouns have syncretic forms in the singular nominative, genitive, and vocative (excluding the 3rd declension).

Table 1.13: Syncretism in the nominative, genitive, and vocative

\begin{tabular}{llll}
\hline SG & $\mathbf{2}(\mathrm{M})$ & $\mathbf{3}(\mathbf{M}, \mathbf{F})$ & $\mathbf{6}(\mathrm{F})$ \\
\hline NOM & akmen-s & liet-us & ziv-s \\
GEN & akmen-s & liet-us & ziv-s \\
VOC & akmen-s! & & ziv-s! \\
\hline
\end{tabular}

The widely represented syncretism of noun cases in Latvian prompts several conclusions. First of all, the following four cases are involved in this syncretism: the nominative, genitive, accusative, and vocative. The nominative, accusative, and genitive represent the so-called central or grammatical cases that are connected with the grammatical structure of a sentence (see in detail the grammatical and semantic functions of cases in Blake 1997, 36-47; Plungian 2011, 165-184). Even if the typical case of the subject is the nominative case and the accusative typically is the object case, in Latvian both functions can also be performed by the genitive (see for details Section 1.5). This variety of syntactic structure is indirectly revealed also by the fact that case syncretism is most widely found in the nominative, accusative, and genitive (see Tables 1.9, 1.11, 1.12). The presence of the vocative, which belongs neither to the core nor peripheral cases, in Latvian noun case syncretism is not surprising, because the existence of this syncretism is determined by the common functions of the nominative and vocative cases (in detail see Section 1.3.2). 
Second of all, peripheral cases (the dative, instrumental, and locative) are minimally involved in syncretism. The dative is involved only in one instance: the dative and instrumental syncretism of nouns in all declensions in the plural (see Table 1.8). The instrumental is connected with two instances of syncretism. The first instance is the syncretism of nouns of all declensions in the singular accusative and instrumental. The second instance is the syncretism of the 1st, 3rd, and 4th declension nouns in the singular accusative and instrumental and the plural genitive (see Table 1.9). The locative is not connected with syncretism.

Third of all, case syncretism in Latvian is not connected with gender or animacy, because it is realised irrespective of the lexical meaning of the noun. This feature of syncretism distinguishes Latvian from other Indo-European languages where similar instances of syncretism can be found (regarding this see Blake 1997, 41-47).

Case syncretism in Latvian is caused by:

1. historical homonymy of forms due to reduction in final syllables;

2. original forms, due to analogy, have been replaced by other forms;

3. alternation of the syntactic usage of these case forms.

This noun case syncretism has also resulted in different approaches for describing the Latvian noun case system. It seems that the most prominent discussions are connected with the syncretism of the accusative and instrumental (in singular) and the dative and instrumental (in plural) found in all declensions as well as the syncretism of the nominative and vocative. These instances of syncretism are also connected with the fundamental approach to the entire case paradigm, in particular, the question of how many noun cases Latvian possesses - six or seven (NOM, GEN, DAT, ACC, LOC, VOC or NOM, GEN, DAT, ACC, INS, LOC) or only five (NOM, GEN, DAT, ACC, LOC). For this reason the instrumental and vocative have become problematic. The trend to decrease the number of the cases in Latvian is observable not only in scientific descriptions of Latvian (see for example Eckert, Bukevičiutè, Hinze 1994; Nītiṇa 2001) but also in various bilingual textbooks and other sources devoted to Latvian (for example Andronov 2002; Klēvere-Velhli, Naua 2012). For this reason there are two topical issues. First of all, have the instrumental and vocative really ceased to exist in the grammatical system of Standard Latvian? Second of all, what has happened with the grammatical and semantic functions of these two cases? Have these functions all been overtaken by other cases thereby entirely subsuming the instrumental and vocative?

The instances of ACC-INS SG / DAT-INS PL and NOM-VOC syncretism are also closely connected with the evolution and development of Latvian and the previously mentioned causes of case syncretism. Therefore, the next two sections are devoted to the issues connected with the instrumental and vocative. Case alternation in relation to case syncretism will be further discussed in the context of the functions of case forms (see Section 1.5). 


\subsubsection{Instrumental}

The problem of the instrumental had already been brought up by Endzelins (1971a [1897]; 1971b [1901]) and by Endzelīns \& Mīlenbachs (1934 [1907]) in their analysis of the noun declension paradigm as well as various instances of preposition use in Latvian. The controversial considerations regarding the instrumental are also included in Standard Latvian grammatical system descriptions (for example Mathiassen 1997, 41-42; Kalme \& Smiltniece 2001, 99; Nĩtina 2001, 14; Paegle 2003, 37-38). A range of articles have been devoted to the arguments for or against the instrumental. Among these the following articles are the most prominent: Fennells (1995a), Nitina (1997), Kalnača (1999), Grīsle (2007).

The main arguments for the exclusion of the instrumental from the Latvian declension paradigm, as has already been mentioned in Section 1.1, are connected with case forms. Namely, the syncretism of case forms across all declensions with the accusative in the singular and with the dative in the plural as well as the use of the preposition ar 'with'. As a result, the instrumental is the only analytical noun case and as such is in opposition to the all other case forms. These case forms are all synthetic, and therefore the inclusion of the instrumental is thought to contradict the formation of case forms (Nïtina 2001, 14; Smiltniece 2013, 352).

Paradoxically, none of the research arguing for the the exclusion of the instrumental from the Latvian noun case paradigm has pointed out or offered a solution regarding how to view the semantics and functions of the instrumental in morphology and syntax that obviously does not correlate with the usage of the accusative and dative in Latvian. In addition, the fact has been often ignored that the instrumental in Latvian also is used as a synthetic form without the preposition ar 'with'. Here are some examples:

a.

$\begin{array}{llcll}\text { man } \quad \text { ir } & \text { škivis } & \text { zilu } & \text { malu } \\ \text { I.DAT } & \text { be.PRS.3 } & \text { plate.NOM.M } & \text { blue.INS.F } & \text { fringe.INS.F } \\ \text { 'I have a plate with blue fringe' } & & \end{array}$

b. iet

kājām

go.INF foot.INS.PL.F

'go on foot'

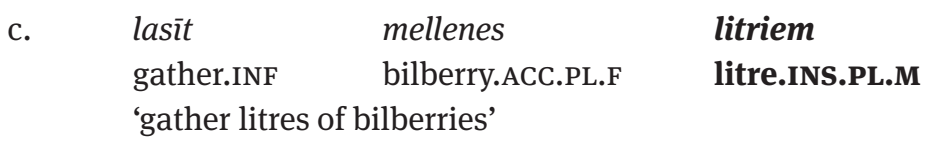

It should be noted that the synthetic instrumental is the primary form in the noun case paradigm. It is still used in Latvian, although considerably less frequently than 
the prepositional instrumental (in detail see Endzelīns \& Mīlenbachs 1939, 136 -138; Paegle 2003, 43; Grīsle 2007, 148-149). However, it is not correct to assert that the instrumental is always used with the preposition ar 'with' (see for example Mathiassen 1997, 41).

Eliminating the instrumental from the noun case paradigm would result in an unclear analysis of the parts of a sentence referring to the direct object and transitive verbs in Latvian. It would also prove problematic in contrasting Latvian with Lithuanian and other related languages. In this regard Grīsle $(2007,149)$ points out:

\footnotetext{
"In what way will we analyse corresponding sentences in Latvian and Lithuanian such as ,iet pliku galvu, pliku kaklu, plikām kājām”: lith. „eina plika galva, pliku kaklu ir nuogomis kojomis” 'to walk bareheaded, barenecked, barefoot'. Wouldn't it be too strange and confusing to consider galvu 'head' and kaklu 'neck' to be accusatives, but kājām 'foot' to be a dative, even if all of them perform the same function in the same sentence? The faultiness of this approach is self evident when the number is changed. And, in the Lithuanian sentence, which fully corresponds to the Latvian sentence, the same forms of the same words have to be labelled as instrumentals!"
}

If the examples of the non-prepositional instrumental given by Grīsle iet pliku galvu, pliku kaklu, plikām kājām 'to walk bareheaded, barenecked, barefoot' due to form syncretism are considered to be accusative and dative, then ignoring word combination semantics, the following question emerges: can transitivity be connected with only the accusative or also with the dative? In that case, there is a curious situation in Latvian where the same word-group is transitive in singular, but intransitive in plural:

(1.23) SG

$\begin{array}{llcll}\begin{array}{l}\text { meitene } \\ \text { girl.NOM.F }\end{array} & \text { ziema } & \text { iet } & \text { pliku } & \text { galvu } \\ \text { 'a girl walks } & \text { bareheaded in winter' } & & \text { bare.INS.F } & \text { head.INS.F }\end{array}$

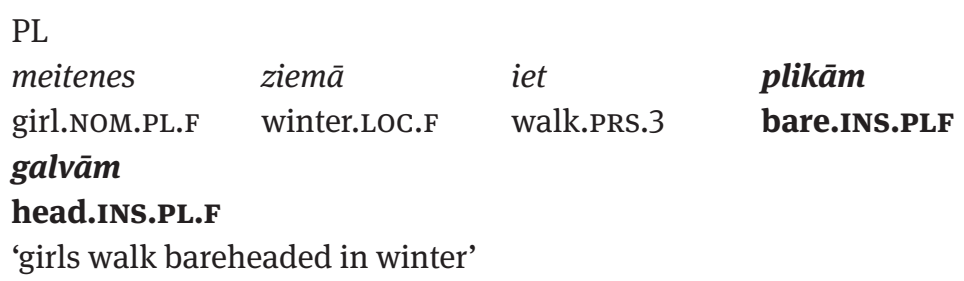

This situation contradicts the essence of transitivity: the ability of a verb to attract the direct object and realise agent-patient relations (Matthews 1997, 383; Crystal $2000,397)$. If the previously exemplified word-groups are viewed from the angle of semantics, it is obvious that pliku galvu, plikām galvām 'bareheaded' irrespective of the number expresses a comitative meaning, i.e., the meaning of an instrument, not 
the meaning of the patient in singular (i.e., direct object) that is a characteristic feature of the accusative, but in the plural that of a beneficiary or experiencer characteristic of the dative (see for example Plungian 2011, 162-165 regarding semantic roles and their functions; see also Holvoet 2012, 93-94 regarding the structural and semantic differences of the accusative and instrumental).

As is known, the syncretism of the accusative and instrumental in singular and the dative and instrumental in plural has been caused by the reduction of final syllable vocalism and various analogous paths of formation (see in detail Endzelīns 1951):

ACC SG rok-u 'of a hand' and INS SG rok-u 'with a hand'

DAT PL rok-ām 'for hands' and INS PL rok-ām 'with hands'

In dialect texts, Latvian folk songs, and texts from the 16th-17th centuries one can find plural instrumental forms containing the ending -is in the masculine gender and -mis in the feminine gender, for example:

a. In the Curonian subdialects of the Middle dialect (spoken in southeastern Courland), these endings can be found even at the end of 20th century and the beginning of 21st century (examples from Ozola 2004, 94-95):

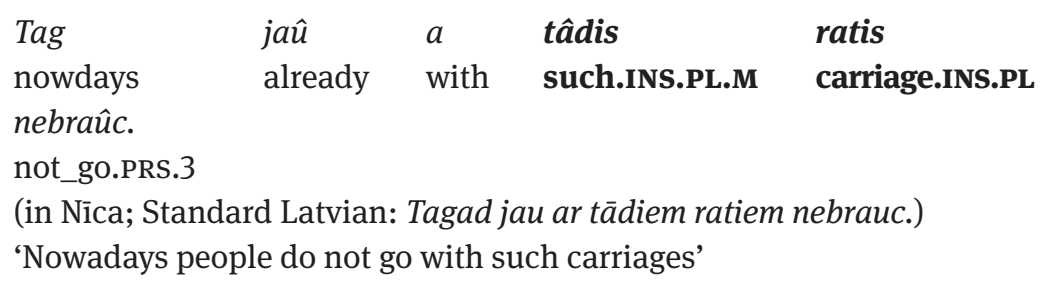

b. In the 1689 edition of the Bible (quoted according to Smiltniece 2002, 57):

$\begin{array}{lllll}\text {..un } & \text { wissa } & \text { ta } & \text { Nauda/ } & \\ \text { and } & \text { all.NoM.F } & \text { this.NOM.F } & \text { money.NOM.F } & \\ \text { ko } & \text { ikkatrs } & \text { labbis } & \text { Prahtis } & \text { dod.. } \\ \text { what } & \text { anyone.NOM.M } & \text { good.INS.PL.M } & \text { mind.INS.PL.M } & \text { give.PRS.3 }\end{array}$


(Standard Latvian: ..un visa tā nauda, ko ikkatrs ar labiem prātiem (labprāt) dod..)

'..and all the money that anyone willingly gives away..'

c. In folk songs (quoted according to Gāters 1993, 165):

$\begin{array}{llll}\text { Kas } & \text { manim } & \text { biedris } & n \bar{a} c a ? \\ \text { who.NOM } & \text { I.INS } & \text { companion.INS.PL.M } & \text { come.PST.3 } \\ \text { Dieviňš } & \text { man } & \text { biedris } & n \bar{c} c a \text {. } \\ \text { god.NOM } & \text { I.DAT } & \text { companion.INS.PL.M } & \text { come.PST.3 }\end{array}$

(Standard Latvian: Kas ar mani biedros nāca, / Dieviņš man biedros nāca.)

'Who was my companion, God was my companion.'

Zinkevičius has noted that in the Lithuanian plural dative and instrumental there is similar syncretism to that found in Latvian (Zinkevičius, 1980, 195-196):

DAT šakóms 'for branches'

INS šakõms 'with braches'

In the High Lithuanian subdialects of Lithuanian, dative and instrumental forms can be used without the intonation distinction and even without an -s ending. For example, rankom 'for hands / with hands' can be both the dative (Standard Lithuanian rankoms 'for hands') and also the plural instrumental (Standard Lithuanian rankomis 'with hands') (Zinkevičus op. cit.). Such forms in these Lithuanian subdialects are analogous to the plural dative and instrumental forms of Standard Latvian and most of its subdialects (see the case paradigm of the Latvian language in Section 1.2).

Nevertheless the syncretism of the forms given by Endzelins \& Milenbachs (1934 [1907], 1939 [1907]), as well as Endzelinns (1951) for the instrumental without the preposition ar 'with' are included in the case paradigm. Phrases containing the preposition $a r$ 'with' have been analysed as forms of the instrumental, not the accusative or dative. This approach for describing the instrumental has been also been employed in Ahero et al. (1959), as well as in scientific grammars and those used in schools beginning in the second half of the 20th century up to the present day. Therefore, the question emerges if this has been done for historical reasons grounded in considerations that the Latvian case system is Baltic and hence a descendant of the system present in ProtoIndo-European, which also included the instrumental case (see Beekes 1995, 172-173). It should be noted that this reasoning was pointed out by Fennell (1995a, 54-61) as the only reliable argument in favour of the inclusion of the instrumental.

The answer to this question could be as follows. Endzelins \& Mīlenbachs, and other authors were of course aware of the fact that form syncretism is an insufficient reason for the complete exclusion of a case from the case system, because each case is defined not only by its unique morphology but also by the specific function it has 
in the language system. The instrumental cannot be combined with the direct object function of the accusative in singular or the functions of the dative in plural (see Section 1.5 regarding the semantics of the accusative and dative). However, the syncretism of ACC-INS SG and DAT-INS PL as well as the loss of the original plural forms of the instrumental may be the main reasons for the preposition ar 'with' appearing in the synthetic cases of the singular and plural paradigm of Standard Latvian. The purpose for using ar 'with' in these contexts was to distinguish syncretic cases with the help of the preposition as well as to strengthen the instrumental semantically (Endzelins 1971b [1901]; see also Paegle 2003, 43).

The most significant reason for the inclusion of the instrumental in the case paradigm is its polyfunctionality with respect to verb arguments - the nouns and adjectives within a sentence. For example, an object in the instrumental normally collocates with a range of verbs that frequently are reflexive verbs expressing reciprocal action (Kalnača 1999):

(1.27) aprunāties ar kādu 'to talk with someone', tikties ar kādu 'to meet with someone', cīnities ar kādu 'to fight with someone', sasveicināties ar kādu 'to greet someone'

Nouns derived from such reflexive verbs also are connected with the instrumental:

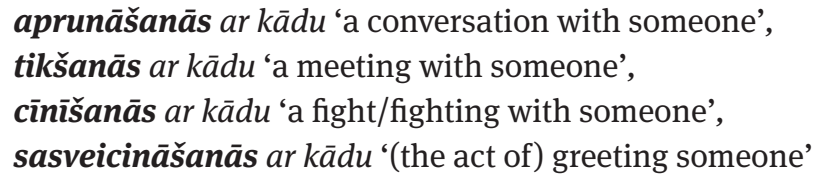

The use of the instrumental, with and without the preposition $a r$ 'with', is versatile in Latvian and can be used with verbs, nouns, or adjectives (see for example Endzelins \& Mīlenbachs 1934 [1907], 136-138; Endzelīns 1951, 580-586; Ahero et al. 1959, 400404, Gāters 1993, 162-183; Paegle 2003, 42-44; Grīsle 2007, 148-149; see also Section 1.5 in the present book), for example:

a. enabling something

\begin{tabular}{|c|c|c|}
\hline $\begin{array}{l}\text { satikties } \\
\text { meet.INF }\end{array}$ & $\begin{array}{l}\text { ar } \\
\text { with }\end{array}$ & $\begin{array}{l}\text { kaiminiem } \\
\text { neighbours.INS.PL.M }\end{array}$ \\
\hline \multicolumn{3}{|c|}{ 'meet with neighbours' } \\
\hline satikšanās & ar & kaimiṇiem \\
\hline $\begin{array}{l}\text { meeting.NOM.F } \\
\text { 'a meeting with } 1\end{array}$ & with & neighbours.INS.PL.M \\
\hline
\end{tabular}




\begin{tabular}{|c|c|c|}
\hline $\begin{array}{l}\text { rakstīt } \\
\text { write.INF }\end{array}$ & $\begin{array}{l}\text { ar } \\
\text { with }\end{array}$ & $\begin{array}{l}\text { zìmuli } \\
\text { pencil.INS.M }\end{array}$ \\
\hline \multicolumn{3}{|c|}{ 'write with a pencil' } \\
\hline rakstišana & ar & zìmuli \\
\hline writing.NOM.F & with & pencil.INS.M \\
\hline
\end{tabular}

b. expressing a feature (usually used without the preposition ar 'with')

$\begin{array}{lll}\text { meitene } & \text { gaišiem } & \text { matiem } \\ \text { girl.NOM.F } & \text { blonde.INS.PL.F } & \text { hair.INS.PL.F } \\ \text { 'fair-haired girl' } & & \end{array}$
sēdèt līku muguru
sit.INF crooked.INS.F back.INS.F
'to sit hunched over'

sēdēšana līku muguru

sitting.NOM.F crooked.INS.F back.INS.F

'(the act of) sitting hunched over'

c. causal meaning (with and without the preposition)

slimot ar anginu
be_ill.INF with tonsilitis.INS.F
'to have tonsilitis/sore throat'

slimošana ar angīnu

being_ill.NOM.F with tonsilitis.INS.F

'having tonsilitis/sore throat'

mirt badu

die.INF hunger.INS.M

'to die of hunger'

Nevertheless, Fennell (1995a) considers the polyfunctionality of the instrumental to be one of the arguments against its inclusion into the Latvian case paradigm. However, this argument seems unconvincing because polyfunctionality is a characteristic feature of all cases in Latvian except the vocative and partially also the nominative (see also Section 1.5 of the present book). In addition, case polyfunctionality is a characteristic feature of other languages, for example, Lithuanian (see Ambrazas 1996, 1997). However, in none of these has this phenomenon been proposed as a reason for unifying cases within the case paradigm. If the function of a case is 
versatile, then certainly there may be instances of case alternation covering situations with similar semantics. However, taking into account all meanings of these cases, it still is possible to postulate the main meaning of the case or the semantic invariant that has served for the contextual derivation of the other meanings. For this reason the existence of case polyfunctionality cannot serve as a reason for the exclusion of cases from a language.

As mentioned in Section 1.1, in Latvian linguistics (much as in the study of other languages) there is an observable inconsistency in the formal understanding of grammatical forms, i.e., in the paradigmatics of verbs both synthetic and analytic forms have been respected, whereas in the paradigmatics of nouns normally only synthetic forms have been respected. Thus, if the versatility of form formation strategies has been acknowledged in the system of verbs, the same approach should be applied to the form formation of nouns. At the same time it must be acknowledged that the entrance of an analytical case form into the paradigm of synthetic forms is a comparatively new phenomenon in Latvian. All the same, the use of the prepositional instrumental form has not resulted in the elimination of the non-prepositional form of the instrumental (regarding this phenomenon see Endzelīns \& Mīlenbachs 1939 [1907], 136-138; Paegle 2003, 42-44). Similar though less developed, non-prepositional and prepositional case alternation is also observable in Lithuanian. Paulauskienè (1994) points out that the noun case forms as well as the prepositional word-group can both be used synonymously to express a particular grammatical meaning (i.e. instrumental meaning) (examples are from Paulauskienè 1994, 104, 132):

rašo pieštuku - rašo su pieštuku 'write with a pen'"

mirè badu - mirè iš bado 'die of hunger'

In this connection it could be noted that Fillmore and Bach also agree that in the deep structure, case forms and prepositional word-groups perform the same function (Fillmore 1968, 1-88; Bach 1968, 90-122). Anderson (2006, 22-24, 48-51), however, has mentioned that the same syntactic relations can be shown with case endings as well as with adpositions. This point has also been noted by Plungian (2011, 184-185) referring to the instances where a locative meaning is expressed.

However, in Latvian, unlike in Lithuanian where this is not the case, syncretism of forms has resulted in the borderline of grammatical synonymity being violated between the synthetic case forms and the prepositional word-group. This is especially true for a range of instances where only the instrumental form with the preposition ar 'with' is grammatically correct, such as in a range of instances where the instrumental is used to refer to the act of enabling. This fact should be taken into account because the instrumental with the preposition ar 'with' helps avoid form syncretism thereby distinguishing the use of the instrumental from the accusative and dative. This, however, does not mean that grammatically and especially semantically the instrumental has disappeared from Latvian. The existence of the instrumental 
is proved by its polyfunctionality and the syntactic relation of many verbs and nominals (nouns and adjectives) as well as by the current use of the non-prepositional instrumental in Latvian.

\subsubsection{Vocative}

There are two reasons for the exclusion of the vocative from the noun case paradigm:

1. the vocative is without its own ending, because it is either identical with the nominative or accusative, or lacking any ending at all (Nìtiņa 1997, 203);

2. the vocative does not have a meaning like other cases and therefore it is not connected with the other parts of the sentence (Ahero et al. 1959, 389; see also Plungian (2011, 178-179) for the historical analysis of these considerations).

Nevertheless, the form and function of the vocative allow for this case to be considered an integral part of the noun case paradigm, instead of just a word formation phenomenon (for this viewpoint see Nau 2011, 146).

First of all, it should be emphasised that morphologically the vocative is not a form that would exist outside the paradigm (see Paulauskienè 1994; Kalnača 1999; Holvoet 2012, 47). The vocative is connected with the rest of the cases by the common stem of the noun as well as the specific grammatical form whose main function is the naming of the message addressee (Plungian 2011, 178). The vocative is the case used for calling someone or getting their attention (Matthews 1997, 397) and its function in a language system is to attract the attention of a message addressee to specific information.

A range of the vocative forms inherited from the Baltic and Indo-European protolanguages remain in use in Standard Latvian (1st, 4th, and 5th declensions). The vocative ending of these forms has been phonetically reduced due to the shortening of final syllables (Rudzite 1993, 181-184), i.e., the ending is a zero morpheme, for example (see also Table 1.5, Section 1.2):

(1.31) tēv-ø! 'father!'

kaimin- $ø$ ! 'neighbour!'

$m \bar{a} s-ø$ ! 'sister!'

māt-ø! 'mother!'

The inherited vocative forms of the 2nd and 3rd declension nouns are syncretic with the singular accusative forms, due to the transformation of the final syllables (Rudzite 1993, 189; Endzelīns 1981, 432):

(1.32) brāl-i! 'brother!'

Mik-u! (the vocative from masculine personal name Mikus) 'Mikus!' 
Some 2nd declension nouns may possess a parallel form ending in a zero morpheme alongside forms ending in $-i$ due to the shortening of the inherited ending (Kalme \& Smiltniece 2001, 104-105; see paradigm Paegle 2003, 48; also Holvoet 2012, 50), for example:

(1.33) brāl-ø! 'brother!', Pēter-ø! 'Peter!', puisīt-ø! 'boy!'

or

brāl-i!, Pēter-i!, puisìt-i!

In colloquial speech accusative forms are widely used with a vocative function for 1st and 4th declension personal names (normally these are not mentioned in grammars):

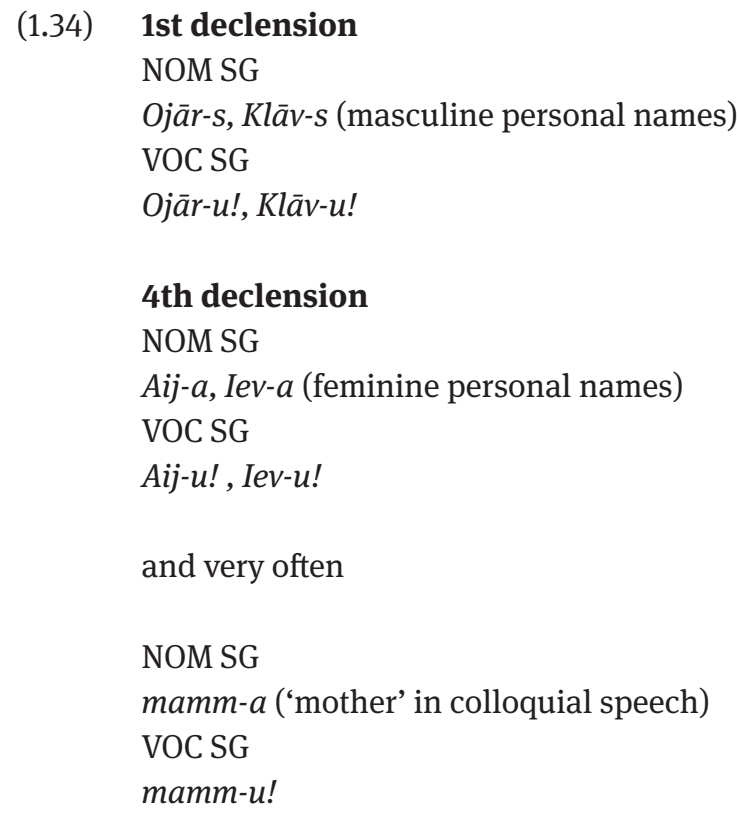

Therefore it would not be reasonable to consider the vocative as a case without its own ending. However, it is correct to say that there is a range of feminine personal names and common nouns of both genders that use nominative case forms functioning as vocatives:

(1.35) Ieva!, Ilze!, kungs! 'gentleman', kundze! 'lady', dēls! 'son' 
However, diminutives with the terminations (the last suffix + ending) -iňs (M), -ina $(\mathrm{F})$, -uks (M), -ēns (M), -itis (M), -ite (F), -ulis (M), -elis (M) always have a vocative form (see about this also Holvoet, 2012, 50) and these terminations are also added to feminine personal names:

a. NOM SG

vīrinš 'husband', sievin,a 'wife', suņuks 'doggie', putnēns 'birdling',

brālittis 'little brother', draudzenìte 'dear friend', ežulis 'little hedgehog',

zirgelis 'horsie'

VOC SG

vīriṇ!, sieviṇ!, suṇuk!, putnēn!, brālīti!, draudzenīt!, ežuli!, zirǵeli!

b. NOM SG

Maijinga, Maijuks, Maijulis, Ilzīte, Ilžuks, Ilžulis

VOC SG

Maijiṇ!, Maijuk!, Maijuli!, Ilzīt!, Ilžuk!, Ilžuli!

The vocative is also used with masculine gender nouns (nomina actionis, i.e., agent nouns) with the terminations -ājs (M), -ējs (M), -tājs (M), (see also Holvoet 2012, 50), whereas feminine gender nouns with the terminations -āja (F), -ēja (F), -tāja (F) have both unique vocative forms as well as nominative forms functioning as vocatives:

a. NOM SG (M)

ēdājs ‘eater', nesējs ‘carrier’, dziedātājs ‘singer'

VOC SG (M)

ēdāj!, nesēj!, dziedātāj!!

b. NOM SG (F)

ēdāja, nesēja, dziedātāja

VOC SG (F)

èdāj! / ēdāja!, nesēj! / nesēja!, dziedātāj! / dziedātāja!

The vocative does not perform the same syntactic functions as the other cases, because it cannot be, like other cases, a subject, predicate, object, adverbial modifier, or apposition in a sentence. This, however, is not an argument for excluding the vocative from the case paradigm. A noun in the vocative case can attract an attribute as well as distinguish the finite forms of a verb, i.e., the number of the predicate in a particular context. As Holvoet $(2012,55)$ points out, 
"The vocative is distinct from other cases because of this syntactic isolation, but it could be viewed as being at the end of a certain continuum: grammatical cases > semantic cases > discourse-oriented cases. Vocative noun phrases may have some specific features (actually some vocatives cannot occur in phrases), but basically they are similar to other noun phrases.”

This fully refers to Latvian. First of all, the vocative is the dialogue case, and therefore closely connected with sentence modality and intonation in the spoken language. Therefore, the vocative normally collocates with the 2nd person verb in singular and plural, and in addition the number form of the verb agrees with the number of the addressed people:

a. SG if one person is addressed

$\begin{array}{llll}\text { Tas } & \text { esi } & t u, & \text { Zvirbulēn? } \\ \text { it.NOM.M } & \text { be.PRS.2sG } & \text { you.NOM } & \text { sparrow.Voc.M }\end{array}$

'Is it you, little sparrow?'

(Viks)

Labi, $\quad k a \quad$ atlidoji, draugs.

good that come.PST.2SG friend.NOM.M

'Friend, it is good you have come'

(Viks)

b. PL if several persons are addressed

Draugi, nāciet pusdienās!

friend.NOM.PL.M come.IMP.2PL lunch.LOC.PL.F

'Friends, you are welcome to lunch!'

(G)

Cilvēki, ejiet uz teātri!

person.NOM.PL.M go.IMP.2PL to theater.ACC.M

'People, go to the theatre to see performances.'

(G)

c. PL forms in politeness phrases, if one person has been addressed in the 2nd person in PL

Aija, uzklājiet lielajā $\quad$ istabā

Aija.NOM.F set.IMP.2PL big.LOC.F room.LOC.F

galdu!

table.Acc.M

'Aija, set the table in the large room!' 


\begin{tabular}{llll} 
Godājamais & \multicolumn{2}{c}{ Ministru } & prezident! \\
honourable.NOM.M & minister.GEN.PL.M & president.Voc.M \\
Padomājiet & labi, & pirms & balsojat! \\
reflect.IMP.2PL & carefully & before & vote.PRS.2PL \\
'Honourable Prime Minister! Carefully reflect before you vote!'
\end{tabular}

If a person is addressed with whom the message sender intends to do something collaboratively, then the vocative collocates with the predicate in the 1st person PL imperative:

a.

$\begin{array}{lllll}\text { Dzintara } & \text { kungs, } & \text { iesim } & \text { ari } & \text { mès } \\ \text { Dzintars.GEN.M } & \text { sir.NOM.F } & \text { go.IMP.1.PL } & \text { too } & \text { we } \\ \begin{array}{l}\text { dejot! } \\ \text { dance.INF }\end{array} & & & \\ \end{array}$

'Mr. Dzintars, shall we both dance?'

(Zālīte)

b. Tagad ar̄̄ mēs parunāsimies, skaistulìt!
now too we talk.ImP.1.PL beauty.voc.F

'And now, beauty, we have a chance to talk!'

(Zìverts)

So, the vocative, like the nominative, can determine the number of the predicate in a particular context. This phenomenon shows the ability of the vocative to collocate with other words in a sentence, i.e., to determine the finite forms (number and person) of a predicate, which is a verb.

As is seen in these examples, the place of the vocative in a sentence is not fixed normally it stands at the beginning of a sentence (see examples (1.38b-c), (1.39a), but it can also stand at the end of a sentence (examples (1.38a), (1.39b), (1.40a) or in the middle (1.40b-c):

a.

$\begin{array}{lll}\text { Nerunā } & \text { mulkīibas, } & \text { Andrej! } \\ \text { not_talk.IMP.2sG } & \text { nonsense.ACC.PL.F } & \text { Andrejs.voc.M } \\ \text { 'Stop talking nonsense, Andrejs!' } & \\ \text { (Zālīte) } & \end{array}$
b. Lūdzu, dakterkundze, ejiet šeit. please madame_doctor.NOM.F go.IMP.2PL here 'This way please, Madame Doctor.'


c. Arjūsu laipnu aț̣aju,

$\begin{array}{lllll}\text { kungs, } & \text { es } & \text { gribētu } & \text { mazliet pakavēties } & \text { šeit. } \\ \text { sir.Nom.F } & \text { I } & \text { want.CoND } & \text { a_little linger.INF } & \text { here } \\ \text { 'With your kind permission, Sir, I would like to linger here for a while.' } \\ \text { (Skujenieks) }\end{array}$

Second of all, a noun in the vocative can agree with an attribute. Holvoet (2012, 5262) explained the ability of the vocative to agree with an attribute not only in the nominative but also in the accusative. This agreement can be seen in the following examples:

$\begin{array}{lll}\text { Adj / } \text { Pron }_{\text {Noм }}+\text { noun }_{\text {voc / Nom }} & & \\ \text { Tu mana } & \text { mīl } \bar{a} & \text { meitenit! } \\ \text { you.NOM } \quad \text { my.NOM.F } & \text { darling.NOM.F } & \text { girl.voC.F } \\ \text { 'You, my darling girl.' } & & \end{array}$

$\begin{array}{lllll}\text { Mans } & \text { puisit, } & \text { jau } & \text { ir } & \text { vēls! } \\ \text { my.Nom.M } & \text { boy.voc.M } & \text { already } & \text { be.PRs.3 } & \text { late.NOM.M }\end{array}$

'My dear boy, it is getting late.'

\begin{tabular}{llll} 
Dārgā & māte, & dārgā & meita, \\
dear.NOM.F & mother.NOM.F & dear.NOM.F & daughter.NOM.F \\
dārgā & $m \bar{a} s a !$ & \\
dear.NOM.F & sister.NOM.F & \\
\multicolumn{2}{l}{ 'Dear mother, dear daughter, dear sister!' } &
\end{tabular}

(1.42) Adj / Pron AcC + noun $_{\text {voc }}$

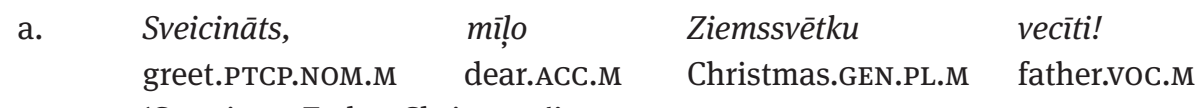
'Greetings, Father Christmas!'

$\begin{array}{llll}\text { b. } & \check{C} \text { au, } \quad \text { manu } & \text { dārgo } & \text { lasītāj! } \\ \text { hi } \quad \text { my.ACC.M } & \text { dear.ACC.M } & \text { reader.voc.m } \\ \text { 'Hi, my dear reader!' } & & \end{array}$




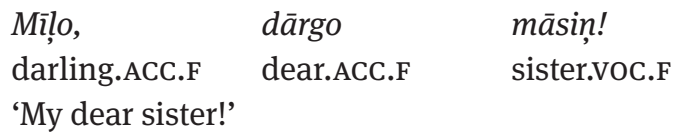

$\begin{array}{lll}\text { Manu } & \text { mìlo } & \text { meitenit! } \\ \text { my.ACC.F } & \text { darling }\end{array}$
$(\mathrm{K})$

(G)

As adjectives, declinable participles, and pronouns do not have vocative forms in Latvian, nominative forms functioning as vocatives are typically used instead. This phenomenon is clearly seen if any word in the aforementioned parts of speech collocates with a noun in the vocative. This would mean that in theory one would expect an attribute that agrees in gender, number, and case. The agreement is realised in the same way as that of an adjective in the nominative (or any other declinable part of speech) agreeing with a noun in the vocative (see examples (1.41)).

It is curious to also see accusative forms with this function. The accusative attribute forms are explainable for adjectives that collocate with nouns of the 2nd and 3rd declensions, as the vocative form of these is syncretic with the accusative form. However, the accusative that collocates with the nouns of the 1st, 4th, and 5th declensions is surprising (see examples (1.42)). Accusative noun forms functioning as vocatives in colloquial speech (see (1.34) examples Ojāru!, Klāvu!, Aiju!, Aiju!) are normally used as isolated vocative forms without collocating with their respective attributes. Therefore, such vocatives should not be regarded as the determiners of accusative attribute forms. It appears that exactly the syncretic vocative and accusative forms of 2 nd declension nouns have determined the agreement of the accusative form of the adjective with the attribute. Perhaps, this has favoured the spreading of the collocation of the accusative form of the attribute to the nouns of the 1st, 4th, and 5th declensions.

However, irrespective of the vocative agreement with other words in the given context, this fact has been ignored in descriptions of the Standard Latvian case paradigm (for example, Smiltniece 2013, 355-366). There are several reasons for this tendency. One of the most important reasons is the alternation of NOM-VOC, i.e., the syncretism of the nominative and vocative. Both cases are linked by a common function (naming), and therefore they are in semantic opposition to the rest of the cases that (in a broad sense) express the relationship among constituents (Blake 1997, 45):

NOM, VOC name an item
GEN, DAT, ACC, INS, LOC

express the relationship among constituents 
Therefore the nominative and vocative, which are considered to be independent cases, tend to contrast with the dependent cases - the genitive, dative, accusative, instrumental, and locative. The semantic difference of the nominative and vocative in relation to the rest of the cases is also observed grammatically, as historically the nominative and vocative are partially marked or completely unmarked forms (Blake 1997, 32; see Endzelīns 1951, 1981, 1982; Rosinas 2005 regarding the history of the Latvian nominative and vocative cases).

Due to the naming function, the nominative and accusative are not polyfunctional, which is their essential distinguishing feature from the rest of the cases that have become widely polysemantic and acquired versatile syntactic use (see the description of case polyfunctionality in Section 1.5).

The nominative and vocative also create interrelated semantic opposition:

$\mathrm{NOM}$
names an item
VOC

names the addressee of a message, normally a living being (a person, domestic animal, or personified item)

In this opposition the unmarked part is the nominative, which only serves to name an item (Blake 1997, 44). The vocative, however, specifies and brings out the named item, i.e., the addressee, as it only can be a living being (or a personified thing). As Plungian $(2011,178)$ points out, the vocative differs from other cases in that it expresses the semantic role of the speech act participant. The required function of the vocative is for the speaker to atttract the attention of the addressee or recipient of that speaker's message.

As the nominative and vocative have a common function, i.e., naming, the nominative as an unmarked part of that opposition can take on the role of the vocative. In such instances, nouns are used with the specific intonation and syntactic context of the vocative thereby causing the competition of these grammatical forms. This phenomenon is observed not only in Latvian but also in Lithuanian (Lithuanian examples from Paulauskienè 1994, 103):

a. $\quad$ VOC
Latvian
Lūdzu, Ėrikas
jaunkundz!
please Ërika.Gen.F Miss.voc.F
'Here you are, Miss Ērika!'

(Zālīte)

$\begin{array}{llllll}\text { Ko } & n u, & \text { Vimbas } & t e \bar{v}, & \text { par } & \text { to } \\ \text { what.ACC } & \text { now } & \text { Vimba.GEN.M } & \text { father.voc.m } & \text { about } & \text { it.ACC.M }\end{array}$


vairs runāt!

more talk.INF

'There is no use talking about it, Mr Vimba!'

(Zālìte)

\section{Lithuanian}

\begin{tabular}{|c|c|c|c|}
\hline $\begin{array}{l}\mathrm{Ka} \\
\text { what.ACC }\end{array}$ & $\begin{array}{l}\text { tu, } \\
\text { you }\end{array}$ & $\begin{array}{l}\text { žmogaus, } \\
\text { person.voc.M }\end{array}$ & $\begin{array}{l}\text { padarysi, } \\
\text { manage.FUT.2SG }\end{array}$ \\
\hline kai & visko & trūksta. & \\
\hline if & whatever.GEN & lack.PRS.3 & \\
\hline
\end{tabular}

b. NOM in the function of VOC

\section{Latvian}

Piedodiet, jaunkundze!

forgive.IMP.2PL Miss.NOM.F

'Sorry, Miss!'

(Eglīis)

$\begin{array}{lll}\begin{array}{l}\text { Tèvs, } \\ \text { father.NOM.M }\end{array} & \text { saki } & \text { tell.IMP. } \bar{t} t \bar{a} \\ \text { cilvēka } & v \bar{a} r d a ! & \text { now that.GEN.M } \\ \text { person.GEN.M } & \text { name.GEN.M } & \\ \text { 'Father, tell me that person's name right now!' }\end{array}$

(Zālìte)

\section{Lithuanian}

\begin{tabular}{|c|c|c|c|}
\hline $\begin{array}{l}\mathrm{Ka} \\
\text { what.ACc }\end{array}$ & $\begin{array}{l}\text { tu, } \\
\text { you }\end{array}$ & $\begin{array}{l}\text { žmogus, } \\
\text { person.NOM.M }\end{array}$ & $\begin{array}{l}\text { padarysi, } \\
\text { manage.FUT.2SG }\end{array}$ \\
\hline$k a i$ & visko & trūksta. & \\
\hline & whatever.GEN & lack.PRS.3 & \\
\hline
\end{tabular}

A similar phenomenon is found also in Latin, Greek, and the Slavonic languages (Coleman 1976; Jakobson 1971a; Rāta 1983). In the competition of the nominative and vocative forms, the nominative has won in most Indo-European languages. Therefore, in these languages, unlike in Baltic, some Slavonic languages, and Ancient Greek, the vocative has not been distinguished as a case with its own ending (Jakobson 1971a, 115-116, 1971b: 179; Rāta 1983, 111-130). In Latin and Modern Greek only the masculine gender o-stem words (that correspond to the 1st declension in Latvian) possess the specific inherited forms of the vocative (examples from Adams 1978; Blake 1997): 


\author{
Latin \\ dominus - domine! \\ 'master - master!' \\ Modern Greek \\ $\dot{\varepsilon} \mu \pi о \rho о \varsigma-\dot{\varepsilon} \mu \pi о \rho \varepsilon !$ \\ 'merchant - merchant!'
}

In all other cases the nominative is used, accusative forms functioning as vocatives are used less frequently (Adams 1978, 16; Blake 1997, 5).

So far it still cannot be stated that the vocative has been completely displaced by the nominative in Latvian. This can be shown by the existence of vocative forms in the 1st, 2nd, 3rd, 4th, and 5th declensions that are still widely used in spoken and written language. Nevertheless, it must be noted that the nominative of particular common and proper nouns in Standard Latvian is used with a vocative function. For example, the aforementioned words: kungs 'gentleman', kundze 'lady', Ieva, Ilze. However, the alternation of the nominative and vocative is proof that the vocative is a unique case and is not an isolated form of address existing outside of the Latvian noun case paradigm.

Taking into account the problems discussed regarding the paradigmatics of the instrumental and vocative, it can be concluded that the dominant view among specialists is that in the Latvian grammatical system is that grammatical meaning can be expressed only by the particular morphemes that are involved in the formation of particular grammatical forms, i.e., the endings (for detail see Kalnača 2000b). However, the formation of the instrumental and partly also the vocative in Standard Latvian differs from the system used for forming the other cases. This fact has been proposed as one of the main arguments against the inclusion of these cases in the case paradigm. Thus the semantics and functions of the instrumental and vocative which cannot be "moved" to other cases within the language system have been completely ignored.

\title{
1.4 Reflexive Nouns
}

Reflexive nouns, due to their semantics and case paradigms, have been traditionally considered as one of the marginal elements of noun system. The existence of these nouns in Latvian is mentioned in Latvian grammars and other descriptions of the grammatical system. It is also often stated that they lack case forms and descriptions of their semantics and semantic functions are rather concise (see for example, Endzelīns \& Mīlenbachs 1939, 43; Ahero et al. 1959, 423; Paegle 2003, 53; Smiltniece 2013, 366 367). It must be noted that the description of reflexive nouns in Latvian linguistics has not noticeably changed since the publication of the Latvian grammars of Endzelīns \& Mīlenbachs (1934 [1907] and 1939 [1907]). Information regarding reflexive nouns is 
also not found in the most recent study by Rosinas (2005) of the Latvian case system. Meanwhile, reflexive nouns are widely used across a range of Latvian registers such as business communication, fiction, mass media, and conversation. All registers in Latvian reveal a curious grammatical phenomenon regarding reflexive nouns: the missing case forms are compensated through the use of other grammatical forms or the joining of case forms in the reflexive noun paradigm. However, so far there have not been any in depth studies shedding light on these issues in Latvian linguistics. This gap reveals the topicality of reflexive noun research.

Reflexive nouns are formed from reflexive verbs with various terminations (Nìtina 2001, 20; Barbare 2002, 78; Kalnača 2011, 72):

a. the termination -šanās expresses processes as subjects in the feminine gender

(similar to verbs with -ing forms (gerunds) in English)

mazgāties : mazgāšanās (F)

'to wash [oneself] : washing [oneself]'

b. the termination -umies denotes the result of middle action in the masculine gender

vēlēties : vēlējumies $(\mathrm{M})$

'to wish [for oneself]: a wish [for oneself]'

c. terminations - tājies, -tājā̄s, -ējies, -èjjās encode the meaning of nomina agentis

and denote the agents of actions expressed by reciprocal verbs of both genders

smieties : smējējies (M), smējējās (F)

'to laugh: the one who laughs'

peldèties : peldètājies (M), peldètājās (F)

'to swim : a swimmer'

With regard to meaning, these nouns retain the reflexive verb meaning alongside the nominal meaning assigned by a word formation suffix -šan- and reflexive ending -ās:

(1.48) celties : celšanās

'to get [oneself] up: getting [oneself] up'

vēlēties : vēlēšanās

'to wish [for oneself]: a wish [for oneself]'

runāties : runāšanās

'to talk [to oneself]: talking [to oneself] 
Meanings connected to unexpected actions are also possible:

(1.49) iesāpēties : iesāpēšanās

'to ache : aching'

Some reflexive nouns have retained the meaning of the passive reflexive verb:

$$
\begin{aligned}
& \text { glabāties : glabāšanās } \\
& \text { 'to keep : keeping' }
\end{aligned}
$$

The merging of non-reflexive and reflexive noun semantics can be observed in Standard Latvian, because, for language users, the distinction of reflexive semantics in the derived nouns has lost its topicality. This is evident as a portion of reflexive nouns commonly used in fiction and other texts have become infrequent. As a result the functions of nouns with the terminations such as -umies, -ējies, -tājies are performed by the relevant non-reflexive nouns:

$$
\begin{aligned}
& \text { vēlējumies (REFL) - vēlējums (NREFL) } \\
& \text { 'wish [for oneself] - wish' } \\
& \text { smèjējies, smējējōs (REFL) - smèjējs, smèjēja (NREFL) } \\
& \text { 'laugher [together] - laugher' } \\
& \text { peldētājies, peldètājās (REFL) - peldètājs, peldētāja (NREFL) } \\
& \text { 'swimmer [together] - swimmer' }
\end{aligned}
$$

As is noted by Kalme \& Smiltniece (2001, 112): "Nowadays these derivatives are not productive in the language, even if, in contrast to non-reflexive nouns, their usage would be motivated and even preferable.“

Currently, the most frequent reflexive noun termination is -šanās that can be used to form nouns from all reflexive verbs (Ahero et al. 1959, 423; Nitina 2001, 20; Barbare 2002, 78; Paegle 2004, 53). In addition, the difference in meaning between non-reflexive and reflexive nouns normally is the same as the difference in meaning of the words from which the noun forms were derived; for example, the difference in meaning of non-reflexive and reflexive verb pairs where the agent and patient fully or partly coincide (see Section 7.2):

$$
\begin{aligned}
& \text { mazgāt - mazgāties } \\
& \text { 'to wash [somebody or something] - to wash [oneself]' } \\
& \text { mazgāšana - mazgāšanās } \\
& \text { 'washing - washing [oneself]' }
\end{aligned}
$$

Irrespective of the close interrelation of reflexive noun and verb systems, they each possess distinctive features. The most noticeable difference refers to the paradigmatics 
of the grammatical forms. The system of finite and non-finite forms of non-reflexive and reflexive verbs is symmetrical (see in detail Kalnača 2004a, 54-57, see also Kalnača \& Lokmane 2012), whereas the system of noun forms is not symmetrical.

Case paradigms of reflexive nouns are defective, as they lack several cases in singular and plural: dative and locative in singular and plural and instrumental in plural (for examples see case paradigms of reflexive nouns in Nītina 2001, 21; Paegle 2004, 53; Smiltniece 2013, 366-367). Examples of this phenomenon can be seen in the case paradigm comparison of the non-reflexive noun mazgāšana 'washing' and reflexive noun mazgāšanās 'washing [oneself]' (Tables 1.14 and 1.15):

Table 1.14: The paradigm of the non-reflexive noun mazgāšana 'washing' (F) (Kalnača 2011, 74)

\begin{tabular}{lll}
\hline & SG & PL \\
\hline NOM & mazgāšan-a & mazgāšan-as \\
GEN & mazgāšan-as & mazgāšan-u \\
DAT & mazgāšan-ai & mazgāšan-ām \\
ACC & mazgāšan-u & mazgāšan-as \\
INS & $($ ar) mazgāšan-u & (ar) mazgāšan-ām \\
LOC & mazgāšan- $\bar{a}$ & mazgāšan-ās \\
VOC & mazgāšan-a! & mazgāšan-as! \\
\hline
\end{tabular}

Table 1.15: The paradigm of the reflexive noun mazgāšanās 'washing [oneself]' (F) (Kalnača 2011, 74)

\begin{tabular}{lll}
\hline & SG & PL \\
\hline NOM & mazgāšan-ās & mazgāšan-ās \\
GEN & mazgāšan-ās & mazgāšan-ās \\
DAT & - & - \\
ACC & mazgāšan-os & mazgāšan-ās \\
INS & (ar) mazgāšan-os & - \\
LOC & - & - \\
VOC & mazgāšan-ās! & mazgāšan-ās! \\
\hline
\end{tabular}

The difference between the non-reflexive and reflexive noun paradigms is obvious. In addition, the paradigm of the reflexive noun mazgāšanās 'washing [oneself]' shows that, apart from the lack of dative and locative cases, there is also case syncretism. Reflexive nouns, in contrast to non-reflexive nouns, possess only two distinct endings $-\bar{a} s$ and -os, which means that in each particular case their semantics depend on contextual use and syntactic function in a sentence. 
Somereflexive nouns arealso considered defective because they are predominantly used in singular, for example, apsēšanās 'sitting down', smiešanās 'laughing', skatī̌sanās 'watching'. For this reason, Paegle $(2003,53)$ has presented the reflexive noun paradigm only in singular and explained that normally they are not used in plural. However, there are a number of reflexive nouns that are used in singular and also plural.

\section{(1.53) SG}

$$
\begin{aligned}
& \text { viena vēlēšanās 'one wish' } \\
& \text { viena tikšanās 'one meeting' } \\
& \text { viena vienošanās 'one agreement' }
\end{aligned}
$$

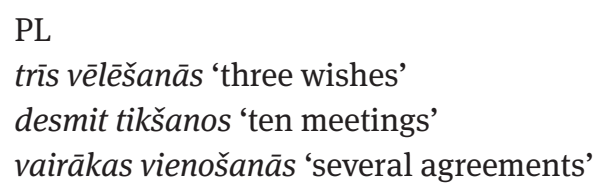

Therefore reflexive nouns should not be viewed as singularia tantum - nouns used only in singular.

The reasons for the paradigms of reflexive nouns being incomplete or defective have not been investigated and so far have been analysed only by Kalnača \& Lokmane (2010) and Kalnača (2011). Defective paradigms are a curious phenomenon in Latvian grammar, as neither colloquial speech nor subdialects display any dative, locative, or instrumental case variants of reflexive nouns that might give any clue to the reasons for this deficiency in determination. This issue is the distinct from that concerning the unclear origin of the dative case forms of paradigmatically similar reflexive declinable participles that Endzelins (1980, 14-15), already during the first half of the 20th century, had pointed out as irrelevant in Standard Latvian. However, he did not provide any further explanation for their possible origin:

\section{(1.54) darbojušamies 'having acted' noskrējušamies 'having run' atrodošamies 'being situated'}

Thus far in their study Kalnača \& Lokmane (2010) have established that along with the deficiency of the dative, locative, and instrumental cases, deficiency also appears in the genitive and nominative cases.

At this point there is no explanation for the reflexive noun paradigm lacking exactly the dative and locative cases as well as instrumental in plural, despite the fact that these cases, especially the dative, have always been and remain vital in the syntactic system of Latvian sentences. Even if it is acknowledged that reflexive noun cases have originated through the fusion of more ancient unabbreviated endings with 
the reflexive noun *si (Endzelīns \& Mīlenbachs 1939 [1907], 43), currently there are no arguments explaining the absence of development of reflexive forms for the dative and locative cases. It seems that there are no phonological or semantic causes for defectiveness of noun paradigms and that the lack of particular case forms might be due to systemic changes in Latvian. It can be assumed only hypothetically that reflexive noun forms have developed simultaneously with the inherited forms of the dative and instrumental in plural, as well as with the transformation processes of the locative (see Endzelins 1981, 416-435 for the history of Latvian noun form development).

However, reflexive nouns have been and remain vital in everyday communication. Reflexive nouns used in colloquial speech, formal texts (for example, legal, business, and academic texts), mass media, and fiction are formed from both inherited (1.54a) and borrowed (1.54b) reflexive verbs, for example:

a. celšanās 'rising' precēšanās 'getting married' sazināšanās 'communicating'

b. absorbēšanās 'absorbtion' koncentrēšanās 'concentration' transformēšanās 'transformation'

All three cases - the dative, locative, and plural instrumental - are vital in reflexive noun involvement in a sentence. As these case forms do not exist in the noun paradigm in the literary language or in subdialects. A curious process has been observed in Standard Latvian: the formation of mixed or heteroclitic paradigms in which nonreflexive noun forms have been used to compensate for the missing reflexive noun case forms (see Table 1.16):

Table 1.16: The heteroclitic paradigm of reflexive nouns (adapted from Kalnača \& Lokmane 2010, 60)

mazgāšanās 'washing [oneself]'

(mazgāšanās 'washing [oneself]'+ mazgāšana 'washing')

\begin{tabular}{lll}
\hline & SG & PL \\
\hline NOM & mazgāšan-ās & mazgāšan-ās \\
GEN & mazgāšan-ās & mazgāšan-ās \\
DAT & mazgāšan-ai & mazgāšan-ām \\
ACC & mazgāšan-os & mazgāšan-ās \\
INS & $($ ar) mazgāšan-os & (ar) mazgāšan-ām \\
LOC & mazgāšan-ā & mazgāšan-ās \\
VOC & mazgāšan-ās! & mazgāšan-ās! \\
\hline
\end{tabular}


This tendency is shown by various examples in Standard Latvian. For example, in a text published in a tourist booklet the lack of a dative singular reflexive noun form has been compensated for by the dative of non-reflexive noun mazgāšana 'washing':

$\begin{array}{llll}\text { Pirts } & \text { visos } & \text { laikos } & \text { ir } \\ \text { sauna.NOM.F } & \text { all.LOC.PL.M } & \text { time.LOC.PL.M } & \text { be.AUX.PRS3 } \\ \text { kalpojusi } & \text { mazgāšanai, } & \text { kermeņa } & \text { sasildī̌̌anai. } \\ \text { serve.PTCP.F } & \text { washing.DAT.F } & \text { body.GEN.M } & \text { warming.DAT.F } \\ \text { 'The sauna has always been used for washing and warming the body.' } & \\ \text { (www.travellatvia.lv) } & \end{array}$

The same compensation tendency can be seen in the use of the singular dative noun forms atvainošanās 'apologizing' and vienošanās 'agreeing':

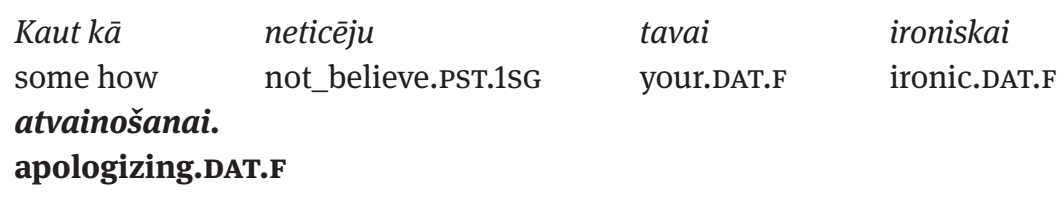

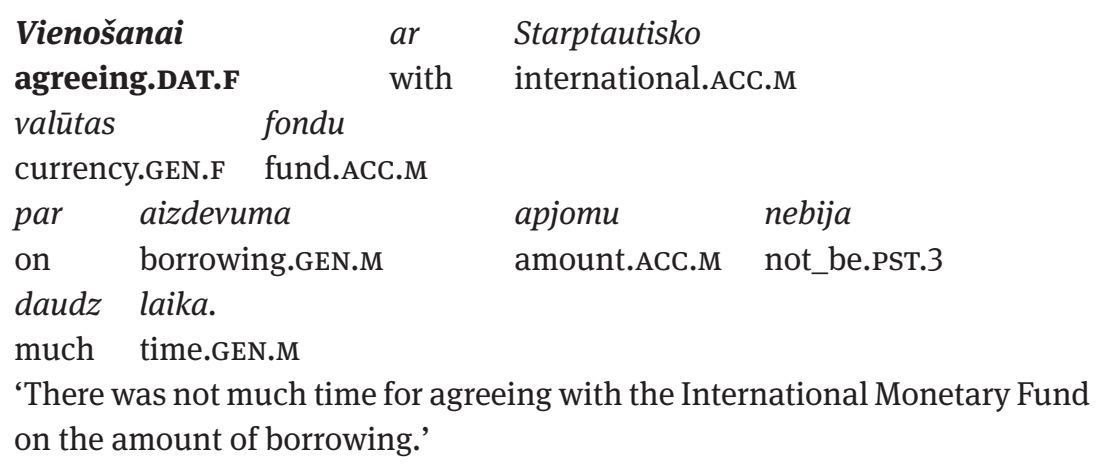

There is also a similar compensation strategy for the plural locative. Thus, for example, the missing singular locative form of the reflexive nouns tikšanās 'meeting' and vienošanās 'agreeing', has been compensated for with the locative of the corresponding non-reflexive nouns:

$\begin{array}{lllc}\text { (1.57) } & \text { Novada } & \text { padomes } & \text { priekšsēdètāja } \\ \text { territory.GEN.M } & \text { government.GEN.F } & \text { head.Nom.F } \\ \text { katrāa } & \text { tikšanā } & \text { uzsver, } & k a . . .\end{array}$


each.LOC.F meeting.LOC.F emphasise.PRS.3 that

'The head of the local government emphasises during each meeting that...'

(Delfi)

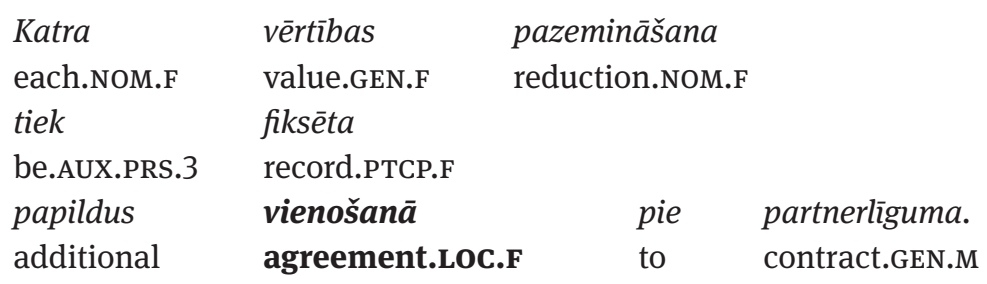

'Each depreciation is recorded in an additional agreement attached to the contract.'

(Apollo)

This same tendency pertains to the plural reflexive nouns in the dative and locative iepazišanās 'getting acquainted', vienošanās 'agreement', tikšanās 'meeting':

(1.58) DAT PL

Sala ir ideāla vieta pirmajām

island.NOM.F be.AUX.PRS.3 ideal.NOM.F place.NOM.F first.DAT.PL.F

iepazišanām ar zemūdens pasauli.

acquaintance.DAT.PL.F with underwater.GEN.M world.ACC.F

'The island is an ideal place for getting acquainted with the underwater world.'

(www.eirozeme.lv)

$\begin{array}{llll}\text { Mutiskām } & \text { sarunām } & \text { vai } & \text { vienošanām } \\ \text { oral.DAT.PL.F } & \text { conversation.DAT.PL.F } & \text { or } & \text { agreement.DAT.PL.F }\end{array}$

nav nekādas jēgas.

not_be.AUX.PRs.3 none.GEN.F point.GEN.F

'There is no point in oral conversations or oral agreement.'

(Apollo)

LOC PL

Šais tikšanās notiek arī

this.LOC.PL.F meeting.LOC.PL.F happen.PRS.3 too

brivas

informal.NOM.PL.F 
$\begin{array}{lccc}\text { diskusijas } & \text { par } & \text { daž } \bar{a} d \bar{a} m & \text { tēmām. } \\ \text { discussion.NOM.PL.F } & \text { on } & \text { various .DAT.PL.F } & \text { topic.DAT.PL.F } \\ \text { 'These meetings also involve informal discussions on various topics.' }\end{array}$

(Apollo)

There are also reflexive nouns in Latvian that do not have a corresponding non-reflexive noun. Even in these cases, the missing reflexive noun forms are compensated for with the forms of non-reflexive nouns, albeit ones that do not exist in the language at all, by merging the non-reflexive and reflexive dative and locative case forms into a single paradigm, or heteroclisis, for example, the nouns piesavināšanās 'appropriatiation' and piesavināšana 'appropriating':

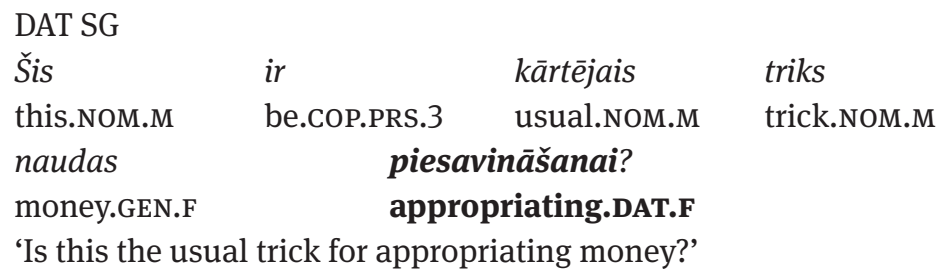

(Diena)

LOC SG

\begin{tabular}{|c|c|c|c|}
\hline Biroja & bijusī & priekšniece & neatzina \\
\hline office.GEN.M & former.PTCP.F & head.NOM.F & not_admit.PST.3 \\
\hline savu & vainu & naudas & piesavināšanā \\
\hline her.ACC.F & guilt.ACC.F & money.GEN.F & appropriation.LOC.F \\
\hline
\end{tabular}

(Diena)

DAT PL

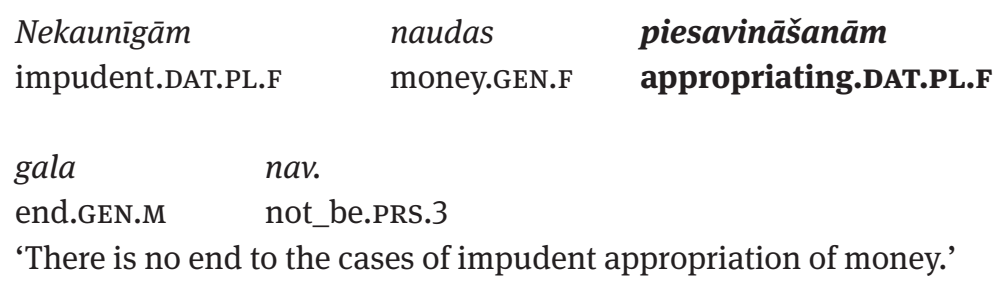

(TVNET)

However, it should be acknowledged that it is complicated to record the use of the full heteroclitic paradigm of any one particular reflexive noun. Certainly there are several nouns that, due to their semantics, are widely applicable both in informal and formal communications, especially in business texts, for example, tikšanās 'meeting', 
vienošanās 'agreement', sazināšanās 'communicating'. Thus, the full heteroclitic paradigms, i.e., all cases in singular and plural, of the aforementioned example words could be recorded.

The use of the dative and accusative non-reflexive noun forms to compensate for the missing reflexive noun forms should be considered erroneous in the Latvian literary language. It would be advisable to compose a sentence so that the dative and accusative of a reflexive noun is avoided by using several separate clauses, participle clauses, or by changing the word order (see Endzelīns 1980, 15 regarding reflexive participle clauses).

As these suggestions tend to complicate the syntactic structure of a sentence, the language users, for the sake of conciseness, still occasionally prefer non-reflexive noun forms in order to compensate for the missing reflexive noun forms.

The existence of heteroclitic noun paradigms indirectly proves the current semantic merging process of non-reflexive and reflexive nouns. Due to this semantic unification some of the previously mentioned reflexive terminations may have become less common. Thus in Standard Latvian, non-reflexive nouns are normally used instead of reflexive nouns with the terminations -umies, -èjies/-èjās, -tājies/tājās, for example:

$$
\begin{aligned}
& \text { atlūgumies }(\mathrm{M}) \rightarrow \text { atlūgums 'resignation' } \\
& \text { klausītājies }(\mathrm{M}) \rightarrow \text { klausittājs ‘listener' } \\
& \text { smējējies }(\mathrm{M}) \rightarrow \text { smējēje ‘laugher' }
\end{aligned}
$$

This trend perhaps is also caused by the fact that reflexive nouns are semantically overloaded derived words and that the action result or the doer have become redundant in relation to reflexivity, gender, number, and case. Therefore, over time through the combination of word formation suffixes and reflexive meaning, the meaning of suffixes $-u m-,-\bar{e} j-,-t \bar{a} j$ - has become dominant instead of the nominalised reflexive meaning embedded in it.

However, in relation to reflexive nouns, there is still a tendency to preserve the defective paradigm in Standard Latvian by employing syntactic means to compensate for the missing cases. But alongside this tendency there is also a morphological compensation mechanism: a heteroclitic paradigm in which non-reflexive noun forms are used to fill in the 'gaps' created by the missing case forms. Perhaps this is due to Latvian being a synthetic language where expression of grammatical meaning is based on synthetic grammatical forms, whereas analytical forms, i.e. syntactic capacities, are viewed as peripheral to its grammatical system.

It should be acknowledged that this phenomenon is not new to Latvian. Already in the novel by Māteru Juris (1879) the locative of a non-reflexive noun in singular cinnišana 'fighting' is used in place of a non-existent locative case form of the reflexive noun cīnišanās 'fighting', see example (1.61): 
(1.61) Turki patlaban sāka vilkties atpakal, kad arī Felzenbergs jau sevi jutās nespēcīgu tālākā cīnīšanā. Bet tomēr viñ̌ turējās uz kājāmm un ... oficierus un zaldātus skubināja uz tālāku cīnišanos.

(Māteru Juris)

'The Turks started withdrawing when Felzenberg had also started feeling himself too weak to continue fighting. But he still managed to keep himself upright and ... encouraged the officers and soldiers to continue fighting.'

Or, for example, in the novel by Jānis Veselis (1931), the missing dative and instrumental case forms of the noun iepazišanās 'making acquaintance' in plural have been filled by the non-reflexive noun form iepazišanām 'making acquaintance', see example (1.62):

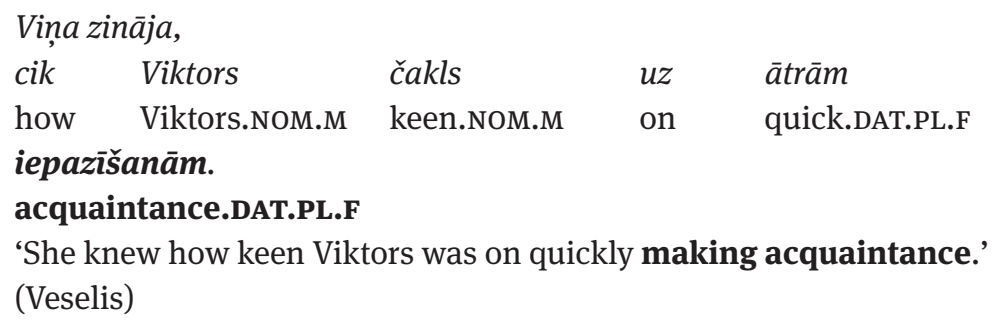

Along with the heteroclitic noun paradigm there is one other compensation strategy used to deal with the missing cases: paradigm unification. In other words, this means that only one form with the ending - $\bar{a} s$ is used for all cases including the missing dative and locative cases. For example, the dative and locative in singular:

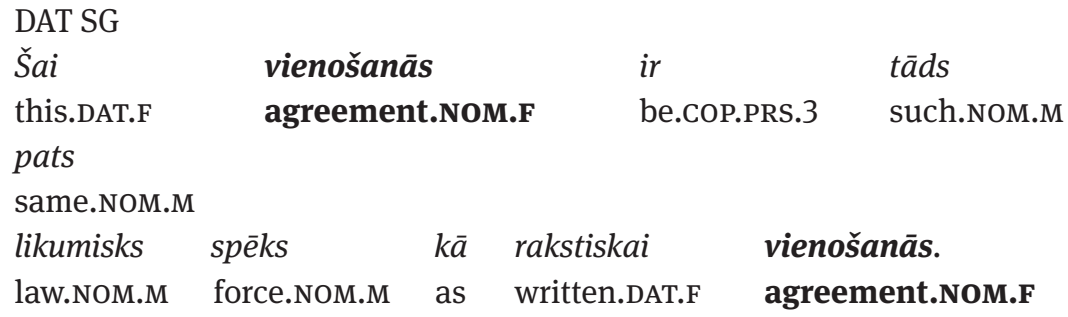

$\begin{array}{llll}\text { Lìdz } & \text { vakara } & \text { ceremonijas } & \text { sākšanās } \\ \text { till } & \text { evening.GEN.M } & \text { ceremony.GEN.F } & \text { beginning.NOM.F }\end{array}$


$\begin{array}{lllll}\text { [olimpiskā] } & \text { lāpa } & \text { tiks } & \text { stingri } & \text { apsargāta. } \\ \text { [Olympic] } & \text { torch.NOM.F } & \text { be.AUX.FUT.3 } & \text { well } & \text { guarded.PTCP.M }\end{array}$

'Before the beginning of the evening ceremony the [Olympic] torch will be well guarded'

LOC SG

\begin{tabular}{llll} 
Latvijas & izdevējus & \multicolumn{1}{c}{ šajā } & tikšanās \\
Latvia.GEN.F & publisher.ACC.PL.M & this.LOC.F & meeting.NOM.F \\
pārstāvēs & Guntars & Lācis. & \\
represent.FUT.3 & Guntars.NOM.M & Lācis.NOM.M & \\
'Guntars Lācis will represent the publishers from Latvia at this meeting'
\end{tabular}

(Apollo)

$\begin{array}{llcr}\text { Ievērojot } & \text { šajā } & \text { vienošanās } & \text { paredzēto } \\ \text { consider.PTCP } & \text { this.LOC.F } & \text { agreement.NOM.F } & \text { envisage.PTCP.ACC.M } \\ \text { darba } & \text { samaksas } & \text { palielinājumu... } & \\ \text { work.GEN.M } & \text { salary.GEN.F } & \text { increase.ACC.M }\end{array}$

'Taking into account the salary increase envisaged in this agreement...'

(Apollo)

An example of an instrumental case form has also been recorded where the reflexive noun iestāšanās 'joining' is used instead of (ar) iestāšan-os, the instrumental form according to the paradigm:

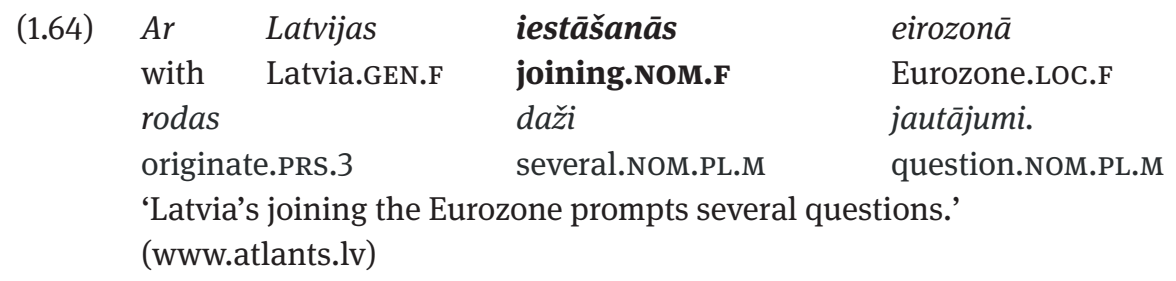

These examples show unification in the reflexive noun case paradigm and demonstrate that the tendency towards the use of only one ending - $\bar{a} s$ is an extreme example of case form syncretism: 
Table 1.17: The unified paradigm of the reflexive noun mazgāšanās 'washing' (adapted from Kalnača 2011, 80)

\begin{tabular}{lll}
\hline & SG & PL \\
\hline NOM & mazgāšan-ās & mazgāšan-ās \\
GEN & mazgāšan-ās & mazgāšan-ās \\
DAT & mazgāšan-ās & mazgāšan-ās \\
ACC & mazgāšan-ās & mazgāšan-ās \\
INS & (ar) mazgāšan-ās & (ar) mazgāšan-ās \\
LOC & mazgāšan-ās & mazgāšan-ās \\
VOC & mazgāšan-ās! & mazgāšan-ās! \\
\hline
\end{tabular}

Syntactically it is possible to identify the case function that has been realised in each particular context, but from the angle of morphology the use of one termination for the meanings of all cases points to paradigm disappearance. This type of reflexive noun use resembles the use of indeclinable nouns that are not typical in Latvian. The small number of indeclinable nouns in use, for example, kino 'cinema', metro 'underground', depo 'depot', ragū 'ragout' are borrowings (in detail see 1.2.2).

The unification of the reflexive noun paradigm, like the previously described paradigm heteroclisis, is not acceptable in literary Latvian. Nevertheless both case form compensation strategies are used rather frequently in Standard Latvian alongside syntactic compensation for the missing cases present in the literary language.

Reflexive nouns and their case system lacking dative, locative, and plural instrumental forms is at the periphery of the Latvian noun system. However, in all registers of Standard Latvian there are widely used reflexive nouns that are formed from inherited as well as borrowed verbs. This is the reason why the missing dative, locative, and instrumental case forms are indispensible to the semantic and grammatical structure of Latvian sentences. There are three types of techniques compensating for reflexive noun defectiveness in Standard Latvian:

1. syntactic constructions (subordinate clauses, participle clauses, etc.);

2. merging of reflexive and non-reflexive noun paradigms resulting in mixed or heteroclitic paradigms;

3. unification of reflexive noun paradigms - the use of one case form for all the other case forms.

Syntactic structures have been considered more relevant in Standard Latvian, even if language users both in written and spoken texts often prefer the morphological compensation mechanism for defective paradigms, which includes the mixed paradigms of reflexive and non-reflexive nouns or, less frequently, paradigm unification. 
The paradigmatics of reflexive nouns should be further researched and our understanding of it enriched by analysis of defective, heteroclitic, and unified paradigms of the reflexive participles. This would lead to more precise conclusions concerning the surface-level and deep structure of Latvian sentences as well as the syntagmatic and paradigmatic features of their structure.

\subsection{Case Polyfunctionality and Case Alternation}

The grammatical and semantic systems of noun categories are currently undergoing some change in Standard Latvian. The most vivid example of such change is found in the category of case and its semantic structure. There we can observe alternation and even concurrence between case forms for different syntactic functions.

The most common are various alternation instances of the genitive and other cases (nominative, dative, accusative) that have been treated differently from the perspective of accepted Standard Latvian. For example, the alternation of the accusative and the genitive is treated as acceptable (Ahero et al. 1959, 394, 398-399; Paegle 2003, 41), while the alternation of the negative forms of the nominative and genitive are considered a divergence from the norm in Standard Latvian (Ahero et al. 1959, 393395, 482; Skujinna 1999, 43; Paegle 2003, 40). Irrespective of the accepted norm, it must be acknowledged that stylistic nuances have emerged in the alternation of the genitive and other cases in the present stage of the development of Standard Latvian. These nuances refer to particular text types and styles as well as the authors' choice of case forms depending on the context or the situation of spoken communication.

The alternation of the genitive and other cases and the reasons for alternation have been analysed by Kalnača (2002a, 2002b, 2007) and also by Novikova (2009). The functions of the dative and the genitive and the alternation with other cases have been described by Berg-Olsen (2005), Holvoet (2011), the alternation observed in the dative and other cases (including the genitive) has been described by Lokmane (2014). Rozenbergs (1983, 20-22) and Kalnača (2011, 60-71) have written about case alternation from the perspective of morphostylistics.

The following discussion analyses the reasons for the alternation of case forms and attempts to explain the reasons for ambiguous grammatical descriptions in Latvian.

Every case form (excluding the vocative) has wide polyfunctionality, which is closely associated with the semantic and grammatical structure of the utterance. The case system, therefore, can be classified as morphologically syntactic (Paulauskienè 1994, 105).

In order to present a comprehensive description of the case alternation instances occurring in Latvian, it is vital to begin the description with a concise overview of the polyfunctionality of all cases (see in detail, for example, Paegle 2003, 38-44; Kalnača 2013, 60-61). 


\section{NOMINATIVE}

1. Subject meaning - the agent of the action (Es lasu grämatu 'I read a book') or experiencer (Es esmu nosalis 'I am cold') functioning as the subject; statement of a fact in nominal predication (Es esmu dzejnieks 'I am a poet'; Tã ir mana grāmata 'This is my book'; Svētdiena parasti ir brīvdiena 'Sundays usually are days off').

2. Object meaning - perceiver of an action or patient (nams tiek celts 'the building is being built', nams ir uzcelts 'the building has been built', man jālasa grāmata 'I must read a book', man sāp galva 'I have a headache').

3. Vocative function (more on this function later, see also Section 1.3.2) - Aija, vai tu iedosi man šo grāmatu? 'Aija, will you give me this book?' Draugi, kas te notiek? 'Friends, what is happening?'

\section{GENITIVE}

\section{Adnominal}

1. Possession - mājas lievenis 'doorstep of the house', tēva grāmata 'father's book', bērza pumpuri 'birch buds', rudens lietus 'autumn rain'.

2. Property - sirds cilvēks 'a person with a big heart', vasaras kvieši 'summer wheat', liela auguma zēns 'a tall boy', rupja maluma milti 'wholegrain flour'; slavas kārs 'ambitious for fame', prieka pilns 'full of joy', ledus auksts 'ice cold'.

3. Material - māla trauki 'pottery', kviešu maize 'wheat bread', stikla vāze 'glass vase', sudraba rota 'silver jewelry'.

4. Content - puḳ vāze 'a vase of flowers', tējas krūze 'a cup of tea', futbola bumba 'a football'.

5. Subject genitive - vēja šalkas 'howls of wind', kaķa n,audiens 'cry of a kitten', bērna prieks 'joy of a child'.

6. Object genitive - siena vākšana 'gathering of hay', dārza ravēšana 'weeding of the garden', dzintara meklètājs 'one who searches for amber'.

7. Adjunct genitive - Liepiņu gimene 'the Liepini family', Liepkalnu mājas 'the house of the Liepkalni [family]', Liepiņa kungs 'Mr. Liepin,š'.

8. Partitive genitive that is normally placed immediately after the word it modifies - tase kafijas 'a cup of coffee', maiss kartupelu 'a sack of potatoes', desmit gadu 'ten years', simt dienu 'hundred days', daudz naudas 'much money', maz prieka 'little happiness'.

\section{Adverbal}

1. Negated subject - nav naudas 'no money', nav laika 'no time', nepietiek vietu 'insufficient places'.

2. The direct object with a negated verb - nepazit cilvēka 'not to know a person', nerakstit vēstulu 'not to write letters', nezināt vārda 'not to know a word'; in Modern Latvian the accusative is typically used instead (discussed later in this section). 
3. Meaning of aim with the verbs lūgt 'to ask', alkt 'to aspire', gribēt 'to want', kārot 'to desire' - kārot svaigu zivju 'to want fresh fish', lügt padoma 'to ask for advice', ilgoties vasaras 'to long for summer'; in Standard Latvian a prepositional phrase with $p \bar{e} c$ 'for' or accusative is used instead (Novikova 2009; Kalnača 2011, 7071):

$\begin{array}{lll}\text { kārot } & \text { svaigas } & \text { zivis } \\ \text { want.INF } & \text { fresh.ACC.PL.F } & \text { fish.ACC.PL.F } \\ \text { 'to want fresh fish' } & \end{array}$

$\begin{array}{lll}\text { lūgt } & \text { padomu } \\ \text { ask.INF } & \text { advice.ACC.M } \\ \text { 'to ask for advice' } & \\ \text { ilgoties } \quad \text { pēc } & \text { vasaras } \\ \text { long.INF } & \text { for } & \text { summer.GEN.F } \\ \text { 'to long for summer' } & \end{array}$

1. Ablative meaning (moving away from something) with the verbs bègt 'to run away', bìties 'to be afraid', baidìties 'to be afraid', sargāties 'to watch out':
sargies
vilciena!
watch.IPM.2SG
train.GEN.M
'watch out the train!'

$\begin{array}{ll}\text { bēgt } & \text { laimes } \\ \text { run_away.INF } & \text { happiness.GEN.F }\end{array}$
'to run away from happiness'

bities soda
be_afraid.INF punishment.GEN.M
'to be afraid of punishment'

In Modern Latvian a prepositional phrase with no 'from' usually is used (Novikova 2009; Kalnača 2011, 70-71):

(1.67) sargāties no vilciena

bēgt no laimes

bìties no soda

2. Partitive meaning denoting part of the whole with the verbs, gribèt 'to want', dzert 'to drink', èst 'to eat'; in Standard Latvian usually accusative is used instead (more on this later in this section): 
gribēt siera

'to want cheese (a small amount)'

dzert kafijas

'to drink coffee (a specific amount)'

èst maizes

'to eat bread (a specific amount)'

\section{DATIVE (usually adverbal)}

1. Object meaning - addressee of an action; the indirect object in relation to the accusative marking the direct object, for example, jautāt mätei 'to ask mother', palìdzèt vecākiem 'to help [one's] parents', kalpot têvzemei 'to serve the fatherland'; aim of purpose of an action - dot ābolu brālim 'to give an apple to brother', rakstìt vēstuli tēvam 'to write a letter to father'.

2. Subject meaning - usually in the debitive mood, man ir jālasa grāmata 'I must read a book', aktieriem ir jāmācās skatuves runa 'the actors have to learn speaking on the stage'.

3. Possessive meaning - man ir nauda 'I have money', man nav naudas 'I don't have money', mūsu ǵimenei ir jauns dzīvoklis 'our family has a new flat'.

4. Experiencer meaning - man ir auksti 'I am cold', man salst 'I am freezing', man sāp galva 'I have a headache'.

Adnominal dative - lìdzīgs mātei 'similar to mother', jautājums tēvam 'a question for father', ticìba ğimenei 'trust in family'.

\section{ACCUSATIVE (usually adverbal)}

1. Object meaning - the direct object next to the verb, lasit grāmatu 'to read a book', èst pusdienas 'to have lunch', rakstit vēstuli 'to write a letter'.

2. Meaning connected with time - strādāt visu nedēḷ 'to work for a whole week', negulèt nakti 'not to sleep at night', lidot divas stundas 'to fly for two hours'.

3. Meaning connected with place (direction) - nākt tālu ceḷ 'to come a long distance', staigāt zināmus ceḷus 'to walk on familiar roads'.

Adnominal accusative - metru augsta sēta 'a fence one meter tall', gadu ilgs pārtraukums 'a one-year break'.

INSTRUMENTAL (usually adverbal; nowadays the original synthetic form is often replaced by a prepositional phrase - see Section 1.3.1 for detail)

iet cepuri galvā 'to walk with a hat on', cimdiem rokā 'gloves on the hands'; škivis zilu malu 'a plate with a blue edge'; meitene gariem matiem 'a girl with long hair'

1. Instrumental or comitative meaning - griezt maizi ar nazi 'to cut bread with a knife', mazgāt rokas ar ziepēm 'to wash hands with soap'; iet pastaigā ar suni 'to go for a walk with a dog', sarunāties ar draugiem 'to speak with friends'. 
2. Meaning connected with time - ar gadiem grāmatu mājās kḷuva vairāk 'with years there were more and more books at home', dienām ilgi list 'it has been raining for days'.

3. Meaning describing manner - ar prieku gaidit ciemos draugus 'to welcome friends with great joy', ar spēku atraut vaḷa $\operatorname{logu}$ 'to pull open the window with force'.

4. Meaning connected with quantity - pirkt audumu metriem 'to buy many metres of fabric', maisiem ābolu 'many sacks of apples', gadiem ilgi krāt pastmarkas 'to collect stamps for years'.

Adnominal instrumental - slavens ar labu virtuvi 'famous for excellent cuisine', pacietīgs ar bērnu 'patient with a child', kurls ar vienu ausi 'deaf in one ear'.

\section{LOCATIVE (usually adverbal)}

1. Meaning connected with place - ielās daudz mašinu 'there are many cars on the street', teātrī daudz skatìtāju 'the theatre house is full of people'.

2. Meaning connected with time - naktīs bieži līst 'it often rains at night', dienā spìd saule 'the sun shines during the day'.

3. Meaning describing manner - visa diena pagāja darbos 'the entire day passed doing hard work', virsdrēbēs neienākt 'do not enter with outdoor clothes on'.

4. Meaning describing purpose - iet viesos 'to pay a visit', iet raudzībās 'to see a new-born child'

Adnominal locative - debesu zilumā 'in the blue of the sky', visā ezera platuma 'across the entire width of the lake', jūras dzilımā 'in the depth of the sea'.

\section{VOCATIVE - the only case which is monosemantic}

The case used for addressing someone - tēvs! 'father!', brāli! 'brother!', māt! 'mother!'

Grammatical polyfunctionality causes an alternation of grammatical forms. The alternation of case forms stems from their syntactic usage - in formal representation of a subject, an object, an address form, or apposition. Thus in Latvian the subject of the utterance can be either nominative or genitive and the direct object can be accusative, genitive, or nominative, etc. Such alternation causes concurrence of case forms. One case form replaces another or both forms function in parallel.

The alternation of case forms had already been attested in Latvian folklore texts, especially in the dainas (Gāters 1993). Endzelīns \& Mīlenbachs had discussed this topic in (1934 [1907], 1939 [1907]). Very similar manifestations of alternation have been found in Lithuanian (for example, Paulauskienè 1994, 2000; Šukys 1998; Valiulytė 1998), Russian (Jakobson 1971; Beloshapkova 1999, 491 etc.), and Latin (Coleman 1976; Blake 1994, 22-23). This is an indication that the alternation of case forms is an old process, which is associated with the unification of functions and specialisation 
of semantic, grammatical, and morphonological systems of language. Manifestation of this process can differ across languages, but the main principles are the same.

The most typical occurrences of alternation of case forms in Latvian are as follows:

4. VOC-NOM in the function of address (discussed in Section 1.3.2)

(1.68) tèv! // tèvs!'

'father!'

5. NOM-ACC in the debitive construction (in detail see Lokmane \& Kalnača 2014)

(1.69) man ir jālasa grāmata // grāmatu

'I must read a book'

6. GEN-NOM

(1.70)

a. in negation

Makā nav naudas // nauda.

'There is no money in the wallet.'

b. for a partitive meaning with indeclinable numerals

Vinam ir desmit gadu // gadi.

'He is ten years old.'

c. for adverbs of measure

Šovasar saules // saule bija tik maz.

'There was so little sunshine this summer.'

7. GEN-DAT for meaning indicating purpose or content

(1.71) puḳu vāze // vāze puḳēm’

'vase of flowers // for flowers'

8. GEN-ACC as a direct object

a. in negation
Neteikšu
neviena
vārda //vārdu.
not_say.FUT.1SG
no_one .GEN.M
word.GEN.M // ACC.M
'I won't say a word.' 
b. for a partitive meaning

$\begin{array}{lll}\text { Bērns } & \text { grib } & \text { siera // sieru. } \\ \text { child.NOM.M } & \text { want.PRS.3 } & \text { cheese.GEN.M // ACC.M }\end{array}$

'The child wants cheese.'

c. for indicating purpose

$\begin{array}{ll}\text { Iesim zivju // zivis } & \text { zvejot! } \\ \text { go.IMP.1PL fish.GEN.PL.F // ACC.PL.F } & \text { fish.INF } \\ \text { 'Let's go fishing!' } & \end{array}$

9. GEN-LOC in possessive meaning

(1.73) Eiropas futbola čempionāts // Eiropas čempionāts futbolā

'The European Football Championship'

The above mentioned examples (1.68)-(1.73) suggest that the alternation of case forms and the development of their polysemic and synonymic systems are closely associated with the transformation of the polyfunctionality of the genitive and nominative. The alternation of case forms declines as some of the primary meanings of the genitive are substituted, or sometimes functions in parallel with other cases or prepositional constructions. There are also observable changes in the polyfunctionality of the nominative that, however, are less prominent because in Latvian the nominative has partly taken up the functions of the vocative (in detail see 1.3.2), whereas in the debitive construction the accusative tends to displace the nominative in the function of an object (see example (1.74)). Nevertheless it must be noted that all changes are primarily linked to the peripheral meaning and not to semantic invariance.

10. NOM-ACC in the debitive construction (in detail see Lokmane \& Kalnača 2014)

man ir jālasa grāmata // grāmatu

'I must read a book'

Replacement of the genitive by other cases is usually explained as a departure from formal syncretism in order to function as a direct object. Thus, in Latvian (in detail see Lepika 1967, 107-115; Berg-Olsen 1999, 175-178; Kalnača 2002a):

a. māsas can be GEN SG

$\begin{array}{lll}\text { Es } & \text { neredzu } & \text { māsas. } \\ \text { I } & \text { not_see.PRS.1SG } & \text { sister.GEN.F } \\ \text { 'I don't } & \text { see } \text { my sister, } & \end{array}$


ACC PL

Es neredzu māsas.

I not_see.PRS.1SG sister.ACC.PL.F

'I don't see my sisters.'

b. $\quad k o k u$ can be

ACC SG

Es neredzu koku.

I not_see.PRS.1sG tree.ACc.M

'I don't see the tree.'

GEN PL

Es neredzu koku.

I not_see.PRS.1SG tree.GEN.PL.M

'I don't see the trees.'

However, this homonymy is not the only reason for case alternation in Latvian. Other reasons are related to case functions within sentence structure.

Every case form has its representative function or semantic invariant (Lyons 1968, 295). The semantic invariant of the subject is nominative; the accusative is the invariant of the direct object, but the semantic invariant of the attribute is the genitive. The genitive in Latvian has also been used in the function of subject and object, as possibly it historically had both of these functions. Thus, the genitive in Latvian has always been polyfunctional, because in contrast to other cases it can be used in a sentence in the following three functions: subject, object, and attribute:

(1.76) GEN as subject

Mājās nav kafijas.

home.LOC.PL.F not_be.PRS.3 coffee.GEN.F

'There is no coffee at home.'

GEN as object

Es nek̄̄a nezinu.

I nothing.GeN not_know.PRs.1SG

'I don't know anything.'

GEN as attribute

Es dzīvoju upes malā.

I live.PRS.1SG river.GEN.F bank.LOC.M

'I live on the river bank.' 
However, over the course of a longer period of time it has become obvious that in Latvian the genitive in the function of subject and object is being gradually substituted with the nominative and accusative, thereby introducing formal homonymy. With respect to the attributive function, apart from the genitive, the dative and locative are also used in the function of attribute. Nonetheless, an analysis of Latvian language material shows that the alternation of case forms is associated with several interlinked processes in the language: the separation of the subject and object domains in the utterance. Specifically, the clear tendency to establish the subject and object domains each with a unique case is the norm in Latvian. The subject of the utterance is typically marked by nominative, while the direct object is accusative, but the genitive tends to preserve only its attributive function. This principle, however, does not refer to the attribute, because in Latvian the attributive function is performed not only by the genitive, but also by the dative and locative. So, the opposite process is observable, i.e., in parallel to the genitive, which functions as the semantic invariant of the attribute, the dative and locative are also used even if they both primarily function as the indirect object and adverbial modifier.

The following sections will outline this schema of semantic invariance and case alternation.

\section{SUBJECT}

NOMINATIVE (semantic invariant)

GENITIVE (subject function)

\section{Case alternation:}

GEN-NOM for a partitive meaning (makā ir desmit latu // lati 'there are ten lats in the wallet')

GEN-NOM in negation (mājās nav cukura // cukurs 'there is no sugar in the house')

The alternation of GEN-NOM for partitive meaning and also for negation have been topical questions since the beginning of the normativization and creation of Standard Latvian in the late 19th and early 20th centuries and remain so today (Endzelins \& Mīlenbachs 1934 [1907], 122; Ahero et al. 1959, 393-395, 482; Lagzdina 1980, 137-143; Lagzdina 1997, 165-200; Skujiṇa 1999, 43; Paegle 2003, 40). It seems that the answer must be sought in the development of the syntactic structure of the utterance and in the syntactic functions of case forms. All the aforementioned examples of GENNOM concurrence are linked to the function of the subject. The semantic and syntactic invariant of the nominative case is the subject of the utterance which is the basic function of the nominative in the language. The genitive can be the subject of an utterance if the predicate is the verb nebūt 'not to be' or trūkt 'to lack', or if the subject is linked with the numerals desmit 'ten', simt 'hundred', tūkstoš 'thousand', or vienpadsmit-devinpadsmit 'eleven-nineteen'. Perhaps this is the principal reason why the nominative tends to challenge the genitive for the position of subject. This process has been continuing irrespective of the standardization of Latvian. 
A noun in the vocative case cannot be the subject of an utterance, but it points to a significant link: the vocative always denotes the subject of the text pertaining to the addressee (in detail see Section 1.3.2). It is possible, therefore, to include the vocative in the subject domain, even though the vocative case cannot be the subject, object, or an attribute in an utterance (Kalnača 1999, 87-93). In addition, the alternation of the nominative and the vocative for the address function also applies to the subject domain. The nominative as an unmarked member of the case paradigm is used in Latvian to function as a vocative with a unique intonation and within a particular syntactic context. This alternation causes concurrence of two grammatical forms: vocative and nominative (Kalnača 2002a, 2002b and Section 1.3.2). This process is not a specific feature of Latvian, but is found in other Indo-European languages with different consequences (Kuriłowicz 1964, 197-199; Jakobson 1971, 179; Coleman 1976, 50; see also Section 1.3.2).

\section{OBJECT}

ACCUSATIVE (semantic invariant)

GENITIVE (object function)

NOMINATIVE (object function)

\section{Case alternation:}

GEN-ACC in negation - neteikšu neviena vārda // nevienu vārdu 'I won't say a word' GEN-ACC for a partitive meaning - bèrns grib siera // sieru 'the child wants cheese' GEN-ACC for indicating purpose - iesim zivju // zivis zvejot 'let's go fishing' NOM-ACC in the debitive construction - man ir jālasa grāmata // grāmatu 'I must read a book'

Currently, the genitive and accusative function in Latvian as grammatical synonyms for the function of object in all possible instances, which creates a rivalry between both cases (Kalnača 2002a, 142-144; Kalnača 2011, 67-70). Taking into account that the meanings of the genitive and accusative are so similar in the aforementioned function, Standard Latvian accepts the use of both cases, depending on the choice of the text author (Endzelīns \& Mīlenbachs 1934 [1907], 171-173; Ahero et al. 1959, 394, 398-399; Paegle 2003, 41).

Even if the alternation GEN-ACC in negation with transitive verbs is currently an active grammatical process in Latvian, it seems the dominance of the accusative case would be premature. It must be acknowledged that in Standard Latvian the accusative is more relevant; in addition, as Rozenbergs $(1983,21)$ has pointed out, the use of the genitive has the connotation of an archaic old usage. Nonetheless, variations in use may be found already in the fiction of the 19th century and the first half of 20th century, Latvian literary works written in exile (since the 1940s), and contemporary fiction. As a direct object in negation, the genitive predominates in older texts, subdialects, and in the spoken language of those who belong to the older generation. For example, 
the genitive is used for direct objects of negated verbs in the literary works of Jānis Ezeriņš, those of Ādolfs Erss written in the first half of the 20th century, and also the works of Anšlavs Eglītis written in exile during the second half of the 20th century:

$\begin{array}{lll}\text { Viņš [princis] } & \text { neredzēja } & \text { vairs } \\ \text { he.NOM.M } & \text { not_see.PST.3 } & \text { more } \\ \text { savu } & \text { ubaga } & \text { drānu (// dränas). } \\ \text { his.GEN.PL.M } & \text { beggar. GEN.M } & \text { clothes.GEN.PL.F // ACC.PL.F } \\ \text { 'He [the prince] } & \text { no longer saw his beggar's clothes.' }\end{array}$

(Ezeriņš)

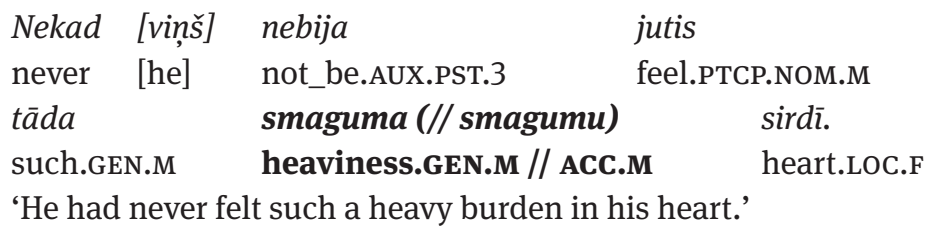

(Erss)

Vezumu rindai vēl nemanija gala (// galu). cart.GEN.PL.M string.DAT.F yet not_notice.PST.3 end.GEN.M//ACC.M 'The string of carts was endless.'

(Eglītis)

Analysing parallel instances of case alternation in Lithuanian, Paulauskienè points out a tendency to use the uniform construction of the accusative for affirmation and negation in Lithuanian (Paulauskienè 1994, 114; Paulauskienė 2000, 176), for example:

$\begin{array}{ll}\text { ACC } & \\ \text { rašau } & \text { laiška } \\ \text { write.PRS.1SG } & \text { letter.ACC.M } \\ \text { 'I am writing a letter' }\end{array}$

GEN-ACC

nerašau laiško // laiška

not_write.PRS.1SG letter.GEN.M // ACC.M

'I am not writing a letter'

There is no semantic difference between the genitive and the accusative in this syntactic position. Hence we must conclude that the genitive has been gradually excluded from the expression of negation in Latvian. This pertains to both a negated subject and a negated object, for example: 
a.

subject

NOM

Šodien

today

ir

saule.

'Today it's sunny.'

be.PRS.3 sun.NOM.F

GEN-NOM

Šodien nav saules // saule.

today not_be.PRs.3 sun.GEN.F // NOM.F

'Today it isn't sunny.'

b. object

ACC

Es pazīstu Maiju.

I know.PRs.1sG Maija.ACC.F

'I know Maija.'

GEN-ACC

Es nepazistu Maijas // Maiju.

I not_know.PRs.1SG Maija.GEN.F // ACC.F

'I don't know Maija.'

The only retained expressions of negation in Latvian are the negative prefix ne- placed before verbs and also the verb nebūt 'not to be'. However, a negated object in the form of the genitive of the pronoun nekas 'nothing' (i.e., the so-called double negation) is frequently used in Standard Latvian:

$\begin{array}{lll}\text { Es } & \text { nekā } & \text { nezinu. } \\ \text { I } & \text { nothing.GEN } & \text { not_know.PRS.1SG } \\ \text { 'I don’t know anything.' } & \end{array}$

$\begin{array}{ll}\text { Man nekā } & \text { nevajag. } \\ \text { I.DAT nothing.GEN } & \text { need.PRS.3 } \\ \text { 'I don't need anything.' } & \end{array}$

Viņam pašlaik nekā negribas.

he.DAT now nothing.GeN not_want.PRS.3

'He doesn’t want anything right now.'

As already mentioned in this chapter, partial inconsistencies can be found in the situation where the alternation GEN-NOM for a negated subject is classified as 
unacceptable in Standard Latvian, yet the alternation GEN-ACC for a negated object is considered acceptable.

The alternation GEN-ACC for a partitive meaning is presumably associated with the fact that the primary semantic opposition specific/general has lost its grammatical topicality in Latvian (Kalnača 2002a, 2002b). In the partitive construction, the genitive indicates a part, whereas the accusative denotes the object as a totality, for example:

\section{(1.80) GEN}

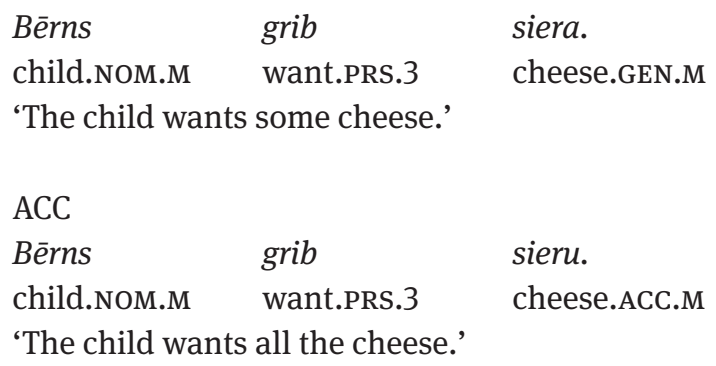

The grammatical expression of this partitive opposition has become lexical. In Modern Latvian, specificity is indicated by the use of adverbs of measure drusku 'some', nedaudz 'a little bit', mazliet 'somewhat', etc.:

$\begin{array}{lll}\begin{array}{l}\text { Bērns } \\ \text { child.NOM.M }\end{array} & \text { grib } & \text { drusku } \\ \text { want.PRS.3 } & \text { some }\end{array}$
'The child wants some cheese.'

The genitive and the accusative currently coexist as grammatical synonyms functioning as objects. This process can be observed in all possible instances, causing alternation of both cases.

The accusative in Latvian dynamically competes with the nominative in debitive constructions, although it contradicts the norms of the standard language (Freimane 1993, 249; Skujina 1999, 41 and 47), for example:

$\begin{array}{lllll}\text { Šo } & \text { banku } & \text { noteikti } & \text { bija } & \text { jāglābj. } \\ \text { this.ACC.F } & \text { bank.ACC.F } & \text { definitely } & \text { be.AUX.PST3 } & \text { save.DEB } \\ \text { 'It was vital to save this bank.' } & & \end{array}$

(Diena)

$\begin{array}{llll}\begin{array}{l}\text { Prezidentu } \\ \text { president.ACC.M }\end{array} & \text { ir } & \text { jāievēl } & \text { jaunajai } \\ \text { partijai. } & & \text { nelect.DEB } & \text { new.DAT.F } \\ \text { party.DAT.F } & & \\ \text { 'The president must be elected by the new party.' } & \end{array}$




\begin{tabular}{|c|c|c|}
\hline $\begin{array}{l}\text { Olimpisko } \\
\text { olympic.ACC.M }\end{array}$ & $\begin{array}{l}\text { ho } \\
\text { ho }\end{array}$ & .ACC.M \\
\hline būs & jāskatās & ierakstā? \\
\hline be.AUX.FUT3 & watch.DEB & record.LOC.M \\
\hline
\end{tabular}

(TVNET)

Lokmane \& Kalnača (2014) point out:

\begin{abstract}
"Currently, what can be observed is a tendency to replace the Nominative by the Accusative. The Accusative argument in the debitive is particularly widespread in spoken language (both in formal and colloquial style). Lately, such a pattern of usage has also been observed in massmedia texts, particularly in the readers' comments thus pointing again to characteristics of the spoken language. The choice between the Nominative and Accusative argument in debitive constructions does not directly depend on the word sequence and on discourse topicalization."
\end{abstract}

NOM-ACC alternations are therefore explainable by the language users' desire to keep the object of transitive verbs in the accusative also for the debitive, i.e., irrespective of Standard Latvian norms equalising the debitive and indicative constructions with respect to their objects:

$$
\begin{aligned}
& \text { Es }\left(\mathrm{S}_{\mathrm{NOM}}\right) \text { lasu grāmatu }\left(\mathbf{O}_{\mathrm{ACC}}\right) \rightarrow \\
& \text { 'I am reading a book' } \\
& \text { Man }\left(\mathrm{S}_{\mathrm{DAT}}\right) \text { ir jālasa grāmata }\left(\mathbf{O}_{\mathrm{NOM}}\right) \rightarrow \\
& \text { 'I must read a book' } \\
& \text { Man }\left(\mathrm{S}_{\mathrm{DAT}}\right) \text { ir jālasa grāmatu }\left(\mathbf{O}_{\mathrm{ACC}}\right) \\
& \text { 'I must read a book' }
\end{aligned}
$$

Inconsistency in standardisation is also evidenced in debitive constructions using the infinitive, for example, Skujina accepts only the accusative if a finite verb in the debitive is followed by an infinitive (Skujina 1999, 47).

$\begin{array}{lllll}\text { (1.84) } & \text { Man } \quad \text { ir } & \text { jāsāk } & \text { laistìt } & \text { dārzu. } \\ \text { I.DAT } & \text { be.AUX.PRS.3 } & \text { begin.DEB } & \text { water.INF } & \text { garden.ACC.M } \\ \text { 'I must start watering the garden.' } & & \end{array}$

Freimane and Paegle allow both the nominative and the accusative in this position, i.e., they are synonymous (Freimane 1993, 249; Paegle 1998, 207).

$\begin{array}{llll}\text { Tev } & \text { ir } & \text { jāturpina } & \text { lasìt } \\ \text { you.DAT } & \text { be.AUX.PRS.3 } & \text { continue.DEB } & \text { read.INF }\end{array}$


grāmata // grāmatu

book.NOM.F // ACC.F

'You must continue reading the book.'

\section{ATTRIBUTE}

GENITIVE (semantic invariant)

DATIVE (attribute function)

LOCATIVE (attribute function)

\section{Case alternation}

GEN-DAT for the meaning indicating possession, purpose, or content (puku vāze // vāze pukèm 'vase of flowers // for flowers')

GEN-LOC for the meaning indicating possession (pasaules basketbola čempionāts // pasaules čempionāts basketbolā 'World Basketball Championship')

The basic function of the dative serves as an indirect object in the utterance:

$\begin{array}{lccl}\text { Es } & \text { rakstu } & \text { vēstuli } & \text { māsai. } \\ \text { I } & \text { write.PRS1sG } & \text { letter.ACC.F } & \text { sister.DAT.F } \\ \text { 'I am writing a letter to [my] sister.' } & \end{array}$

The overview of the dative functions in Latvian presented below (see examples (1.87)) sheds light on the details of GEN-DAT alternation:

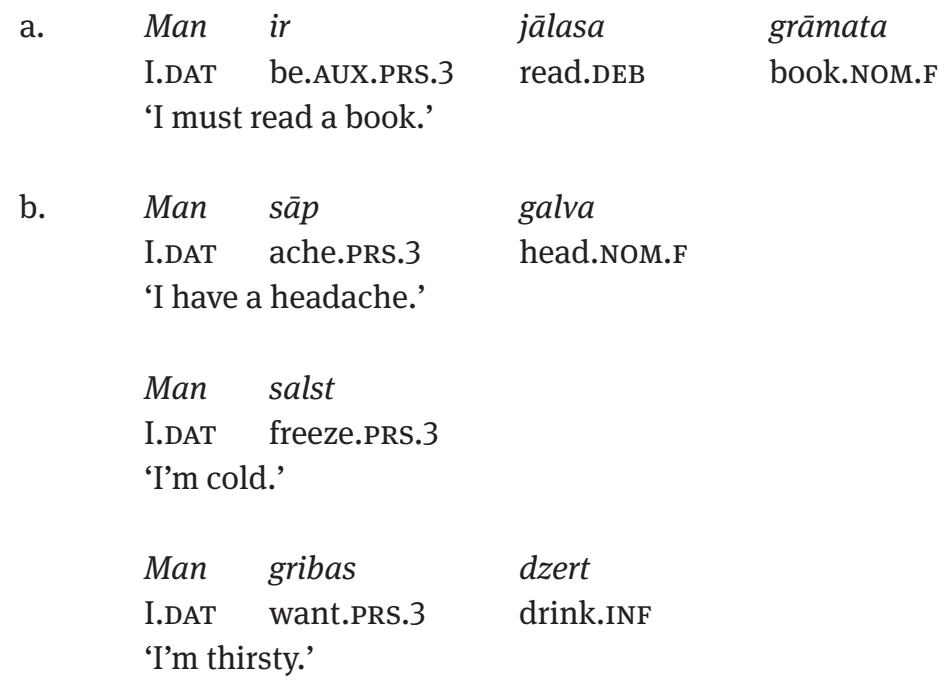




$\begin{array}{lll}\text { c. } & \text { Man ir } & \text { grāmata } \\ & \begin{array}{l}\text { I.DAT be.cop.PRS3 } \\ \text { 'I have a book.' }\end{array} & \text { book.NOM.F }\end{array}$

As can be seen in these examples, the dative functions as an indirect subject and denotes the role of an experiencer (1.87a-b) or beneficiary (1.87c). Richardson (2007, 39), who has focused on similar examples of dative use in the Slavonic languages, labels these dative 'subject' experience constructions, which can be fully referred to Latvian as well. It should be noted that the idea of the dative as subject has a considerably long history in Latvian linguistics. Ozols (1957) proposed this idea by mentioning the term netiešais teikuma priekšmets 'indirect subject' and Freimane (1985), Kārkliņš (1968, 1976, 1985), and Lokmane $(2002,2007)$ have perpetuated this idea. For the analysis of Ozols' ideas see also Freimane (2013), Lokmane (2013), and Vogina (2013). The relation of the dative to the subject function in Latvian is also pointed out in recent research, for example, Seržants (2013a, 2013b) and Holvoet (2013).

Blake also argues that the dative also has a number of functions: i.e. as a direct object, indirect subject as well as an indicator of possession in different languages (Blake 1997, 144-151). This argument supports the inclusion of the dative in the group of central cases (Kuriłowicz 1964: 190-194; see also the analysis of the dative functions found in French (Boneh \& Nash 2013)). The given Latvian dative constructions tend to support the arguments of Blake, Kuriłowicz, and Boneh \& Nash, demonstrating semantic and syntactic asymmetry of the dative compared to other cases. Thus, possession is expressed by both the genitive and the dative in different constructions. This is the semantic background of the alternation of the genitive and the dative in Latvian. A historic link between the meaning of the genitive indicating possession or content and the meaning of the dative indicating purpose or the addressee (i.e. dativus commodi / incommodi) has been established.

In recent decades the concurrence GEN-DAT for meanings indicating possession has been observed in colloquial speech as well as in newspapers, in advertisements, on various signs used in offices and shops, etc. (Kalnača 2011, 64-66), for example:

\begin{tabular}{|c|c|c|c|}
\hline $\begin{array}{l}\text { Māte } \\
\text { mother.NOM.F } \\
\text { // Viṇas } \\
\text { she.GEN }\end{array}$ & $\begin{array}{l}\text { viņai } \\
\text { she.DAT } \\
\text { māte } \\
\text { mother.NOM.F }\end{array}$ & $\begin{array}{l}\text { ir } \\
\text { be.COP.PRS.3 } \\
\text { ir } \\
\text { be.COP.PRS.3 }\end{array}$ & $\begin{array}{l}\text { igauniete } \\
\text { Estonian.NOM.F } \\
\text { igauniete } \\
\text { Estonian.NOM.F }\end{array}$ \\
\hline 'Her mother is Est & tonian.' & & \\
\hline $\begin{array}{l}\text { šampūns } \\
\text { shampoo.NOM.M } \\
\text { šampūns } \\
\text { shampoo.NOM.M } \\
\text { 'a shampoo for ch }\end{array}$ & \multicolumn{2}{|c|}{$\begin{array}{l}\text { bērniem // } \\
\text { children.DAT.PL.M // }\end{array}$} & $\begin{array}{l}\text { bērnu } \\
\text { children.DAT.PL.G }\end{array}$ \\
\hline
\end{tabular}




$\begin{array}{ll}\text { Plāns } & \text { inflācijas } \\ \text { plan.NOM.M } & \text { inflation.GEN.F } \\ \text { // Inflācijas } & \text { ierobežošanas } \\ \text { inflation.GEN.F } & \text { limit.GEN.F } \\ \text { 'A plan for limiting inflation'. }\end{array}$

Plāns

'A plan for limiting inflation'.

\author{
ierobežošanai \\ limit.DAT.F \\ plāns \\ plan.NOM.M
}

(Diena)

However, the GEN-DAT alternation with a possessive meaning is not a new phenomenon in Latvian, as this phenomenon had already been noted and described in the beginning of the 20th century by Endzelīns \& Mīlenbachs (1934 [1907], 178):

\begin{abstract}
"The word boundaries for datives, genitives of possession, and possessive pronouns often end up being close together in the context of a sentence. Compare: Galdam nolūzusi kāja; galda kāja nolūzusi 'The leg of the table has broken off'. Es mātei pirmā meita; es mātes pirmā meita 'I am the first daughter for my mother; I am my mother's first daughter'. For this reason it is no wonder that in western Vidzeme and northern Courland the dative has developed a possessive meaning. [Thus,] throughout all of Courland the dative kam 'to/for whom' has replaced the genitive kā 'whose': Kam dēls tu esi? 'Whose son are you? (in Vidzeme, for example in Lubāne, $k \bar{a}$ 'whose' [would be used in place of kam]).”
\end{abstract}

The alternation of the genitive and dative in the meaning of object is also possible in Lithuanian (Šukys 1998, 156-157; see also example (1.89) from Paulauskienè 2000, 172):

\begin{tabular}{lll} 
Norëjau & paprašyti & \multicolumn{1}{c}{ švarkui (= švarko) } \\
want.PST.1SG & ask.INF & jacket.DAT.M // GEN.M \\
alkūne & užlopyti. & \\
elbow.ACC.F & mend.INF \\
'I would like to ask you to mend the elbow of the jacket.'
\end{tabular}

Holvoet (2011, 79-85), regarding the GEN-DAT alternation in the meaning of possession, points out that in Latvian in contrast to, for example, Lithuanian or Russian, there is no link to the opposition inanimate/animate or static/dynamic in the predicate of a verb. Lokmane (2014), however, points out that static verbs in the predicate are those taking dative arguments, i.e., the verb büt 'to be' is distinguished as one that might tend to have a dative argument. Nevertheless, examples from Latvian, as emphasised by Holvoet in the previously cited pages, do not confirm the aforementioned relation of static/dynamic characteristics of the predicate; see this example containing a dynamic verb in the predicate and a dative instead of the predicted genitive:

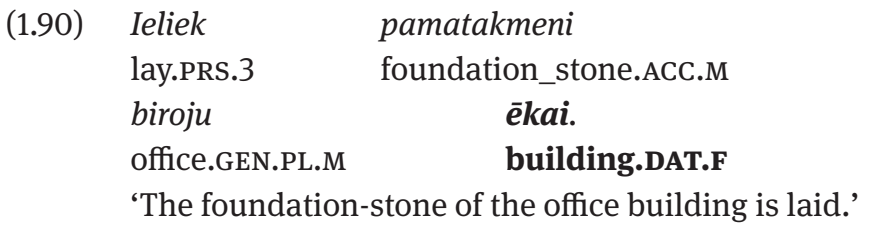


Kalnača (2007 and 2011, 66) points out that 'the dative is a conscious choice of the authors in order to emphasise the contents and aim of the information: what and for what reason has been brought out'. Holvoet (2011, 84-85) also considers that, perhaps, the main reason for alternation is the information, i.e., subordinate rheme emphasis that is done by changing the noun phrase structure: the placing of the attribute after the noun in the dative instead of in the genitive as would be expected.

The GEN-LOC alternation is similar to the previously described alternation and also occurs with a possessive meaning, for example:

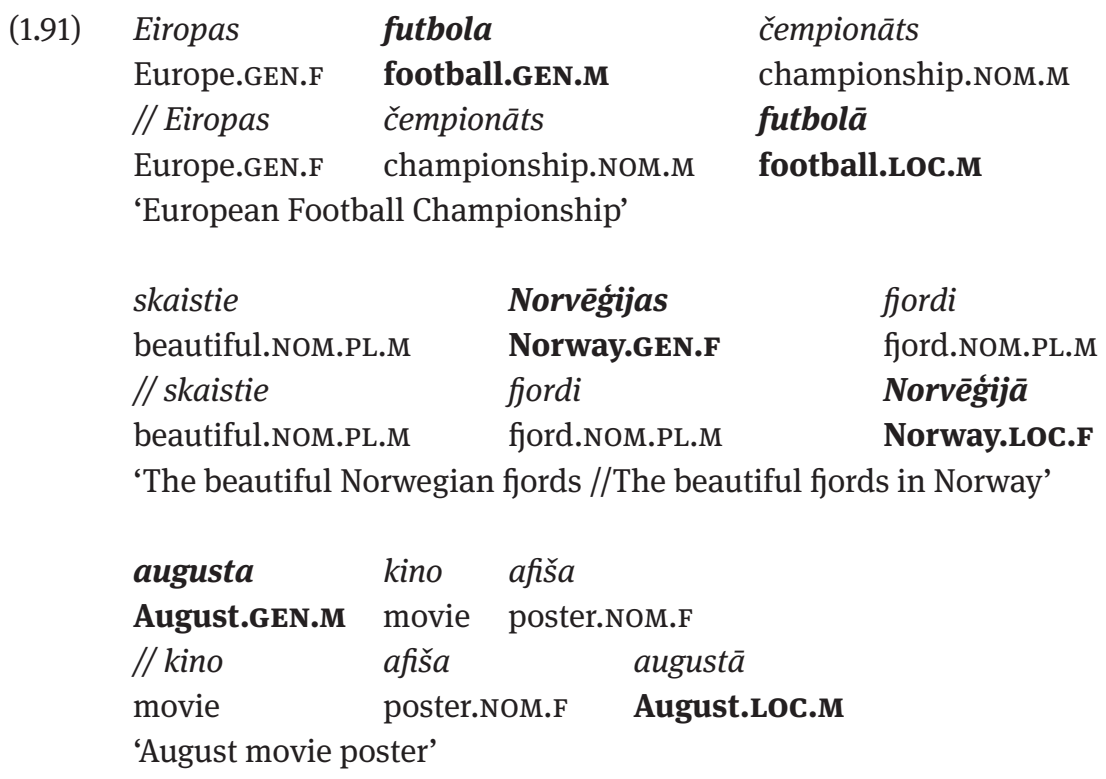

This use of the locative has been observed in the mass media during recent years: in the language used in spoken texts on TV and radio, in the texts of newspapers, magazines and online news sites (Kalnača 2011, 66-67). The GEN-LOC alternation is most widely used in mass media devoted to sports and current events:

(1.92) GEN

$\begin{array}{lccc}\text { Sportists } & \text { pasaules } & \text { peldēšanas } & \text { Čempionātā } \\ \text { athlete.NOM.M } & \text { world.GEN.F } & \text { swimming.GEN.F } & \text { championship.LOC.M } \\ \text { uzrādïja } & 26 . & \text { rezultātu. } & \\ \text { demonstrate.PST.3 } & 26 & \text { result.ACC.M } & \\ \text { 'The athlete at the World Swimming Championship was in 26th place.' }\end{array}$

(Diena) 
LOC

$\begin{array}{llll}\text { Brāḷi } & \text { kluvuši } & \text { par } & \text { Eiropas } \\ \text { brother.NOM.PL.M } & \text { become.COP.PTCP } & \text { about } & \text { Europe.GEN.F }\end{array}$

$\begin{array}{llll}\text { U-20 } & \text { čempioniem } & \text { pludmales } & \text { volejbola } . \\ \text { U-20 } & \text { champion.DAT.PL.M } & \text { beach.GEN.F } & \text { volleyball.LOc.M }\end{array}$

'The brothers have become the U-20 European beach volleyball champions.'

(Diena)

Alternation normally occurs in hierarchically related attributive collocations in which several dependent words are subordinated to one independent noun thus creating attributive groups. The attribute expressed by the genitive, whose possessive meaning in these collocations is also connected with meanings of place and time, in the locative is placed not before, but after the word it modifies. This placement is not characteristic for Latvian. It seems that the reason for this alternation, similarly to the previously described alternation of the dative and genitive, is the intention of the author of a given text to bring out a particular piece of information. However, it must be noted that a sentence with the genitive (instead of the locative) in the meaning of possession is more explicit. The locative possesses other functions: it, adnominally or adverbially, expresses the meaning of location, time, manner, or intention, so the expression of the meaning of possession is not a characteristic feature of the locative (Paegle 2003, 44; Kalnača, 2013, 61). However it is possible that there are morphosyntactic processes in Latvian directed at emphasising the embedded meaning within a sentence by the possessor in the dative or locative in this way partly diminishing the role of the genitive.

In contrast to Lithuanian and other languages, alternation of the accusative and instrumental or the instrumental and dative has not been observed in Latvian (regarding ACC-INS alternation see, for example, Anderson 2011). This demonstrates that there is no basis for omitting the instrumental case from the paradigm of the Latvian case system or assigning its functions to the accusative and dative.

All the above-analysed grammatical processes depend on the syntactic usage of the case form. The nominative assumes the primary genitive function as a subject in the same way as the accusative substitutes for the genitive or the nominative functions as an object. Hence the polyfunctional structure of every case undergoes certain changes. Almost all changes in Latvian are closely associated with different constructions for the genitive. An adnominal genitive continues to function as an attribute, whereas an adverbal genitive is replaced by the accusative in order to function as an object and by the nominative to function as a subject. Examination of case structure points to unification of functions for the surface structure of the utterance, although the core structure remains unchanged. It appears that the assumption of German influence on polyfunctionality and alternation of case forms is not valid (Lepika 1967, 107-115). 
Analogous processes have been established in other languages such as Lithuanian (Šukys 1998, 92-118; Švambarytė 1999, 72-82) and Russian (Blake 1997, 47; Jakobson 1971, 180; Beloshapkova 1999, 491-496; generally about the Slavonic languages see Richardson 2007). The process of unification of functions has perhaps developed further in Latvian than in other languages. Nonetheless it can be objectively verified and it operates relatively independently from the norms of Standard Latvian. A number of regulations have been written trying to stop this process while at the same time, however, treating some instances of alternation as acceptable. This inconsistency in standardisation implicitly points to the objective nature of the changes. The most significant conclusion is: the alternation of case forms is neither a norm nor deviance in Standard Latvian - it is the continuous process of semantic and syntactic evolution.

\subsection{Gender}

Gender is one of the lexico-grammatical categories of the noun. This category is closely connected with the notions of biological gender and animacy (Corbett 2005). An interesting feature of noun gender in Latvian is that it shows semantic and formal asymmetry. On one hand, almost all nouns which are related to human beings, domestic animals, fowl, and some wild animals encode gender deixis. The distinction of feminine and masculine genders is expressed through the use of different markers (Ahero et al. 1959, 379-381; Veisbergs 1999, 49-50; Paegle 2003, 31-32; Kalnača 2008, 28-29):

1. roots in kinship terms

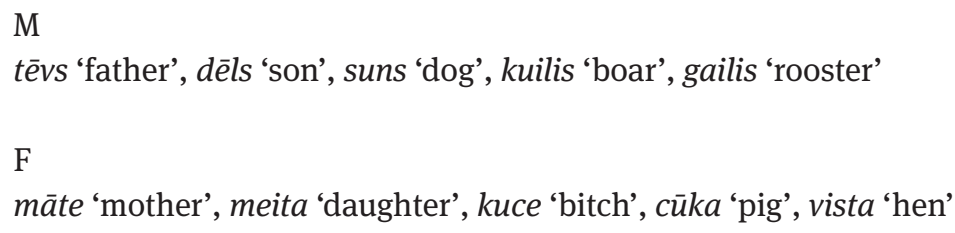

2. endings of terms describing professions or other names of individuals

(1.94) skolotāj-s (M), skolotāj-a (F) 'teacher' pasažier-is $(\mathrm{M})$, pasažier-e $(\mathrm{F})$ 'passenger'

3. suffixes, i.e., endings in terms for ladies of the house, wives, and mothers

(1.95) kalēj-s (M) 'smith', kalēj-ien-e / kalēj-en-e (F) 'smith’s wife, smith’s mother' vilk-s (M) 'wolf', vilc-en-e (F) 'she-wolf' 
4. the terms mother, father, lady, he, or she for ladies of the house, mothers, farmers, owners, fathers, and male as well as female animals and birds:

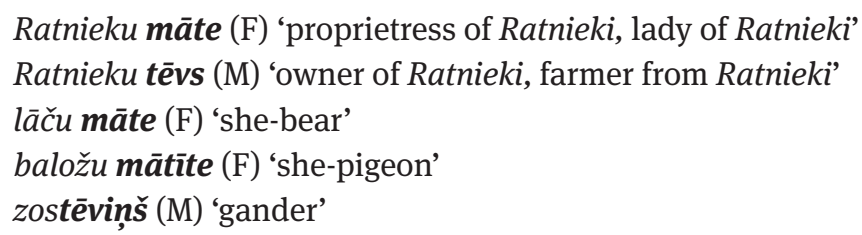

On the other hand, the grammatical gender of other nouns representing inanimate entities or many types of animals, birds, or bugs is a formal feature. The ending or suffix indicates only the declension type (Kalnača 2000, 179-180; Kalnača 2008, 29), for example:

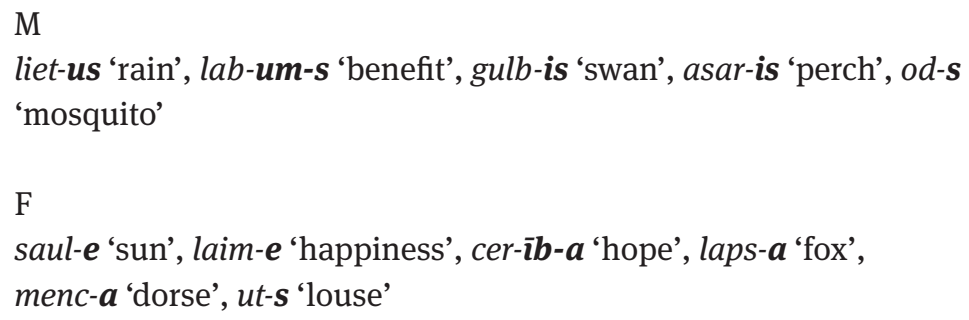

In contrast to the nouns mentioned earlier, these nouns lack gender deixis.

Hence, the gender markers and their functions in language are in part a formal feature and in part directly depend on the animacy and the social position of the respective male or female. This duality of gender is described widely in grammar books, as this phenomenon holds for the majority of languages (for example Ahero et al. 1959, 379-381; Paegle 2003, 31-33; Corbett 2005).

Also, the stylistic functions of gender depend on animacy and gender deixis. Usually nouns related to human beings demonstrate specific stylistic usage which does not reflect the biological or grammatical manifestations of gender. It is common to distinguish among three types of stylistic functions for gender in Latvian:

1. words of common gender (substantiva communia);

2. masculine nouns applied to females;

3. feminine nouns with masculine endings.

These three distinctive types are very characteristic of colloquial Latvian where the use of gender directly depends on the particular speech situation and context. Other stylistic functions of gender, such as poetic usage of gender in fiction as well as gender in advertisements, mass media texts, and formal business correspondence, to name a few, will not be investigated in this book. 
The aforementioned examples of gender usage in colloquial Latvian demonstrate several transpositions of gender markers:

1. neutralization and transposition from grammatical to contextual markers in words of common gender;

2. semantic transposition when masculine nouns and adjectives are related to female human beings;

3. grammatical transposition when nouns with female gender deixis are used with masculine endings or suffixes.

Words of common gender such as auša 'feather brain', tiepša 'mule', plukata 'trash', nejega 'dummy', bezkauna 'shameless person' show neutralization of the ending as the marker of gender when used in colloquial Latvian. All these words have feminine endings in Latvian, although they can designate either a female or male person's qualities or activities. Sometimes gender of the respective noun can be decoded from context (Paegle 2003, 31):

(1.98) vinga ir auša 'she is a feather brain'

or

viņš ir auša 'he is a feather brain'

Thus the real gender marker is the context not the ending of a noun, as context shows whether a female or a male person has been described (all examples in (1.99) from Zālīte (1987)):

\begin{tabular}{|c|c|c|c|}
\hline $\begin{array}{l}\text { Tu, } \\
\text { you.NOM }\end{array}$ & $\begin{array}{l}\text { bezkauṇa, } \\
\text { shameless.NOM.F }\end{array}$ & $\begin{array}{l}t u, \\
\text { you.NOM }\end{array}$ & $\begin{array}{l}\text { netikle! } \\
\text { wanton.NOM.F }\end{array}$ \\
\hline \multicolumn{4}{|c|}{ 'You shameless [person], you wanton [person]!' } \\
\hline & esi & gḷēvulis. & \\
\hline ou.NOM & be.COP.PRS.2SG & coward. & M.M \\
\hline
\end{tabular}

\section{Zaksapastala!}

chicken.NOM.M

'You are a coward! A chicken!'
Nekauņa!
Laulības
pārkāpējs!
shameless.NOM.M
marriage.GEN.F
transgressor.NOM.M
'[You are] shameless! An adulterer!'

Here the gender marker is transposed from the grammatical level to the discourse level as results from gender deixis and the speech situation: 


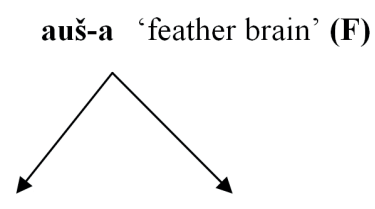

auš-a (F) auš-a (M)

Figure 1.1: Neutralization and transposition from grammatical to contextual gender markers.

It must be pointed out that common gender words usually express derogatory meanings in Latvian. Some are expletives (Ahero et al. 1959, 381; Rozenbergs 1983, 17), for example:

(1.100) plukata 'trash', nejēga ‘dummy’, bezkaun,a 'shameless person’

Only several nouns marked with common gender are completely neutral:

(1.101) pazina 'acquaintance', persona 'person', ekselence 'excellency', augstība 'highness', majestāte 'majesty'

Similar functions of common gender are observed in Lithuanian, Russian, and Polish (Wierzbicka 1996, 398-399; Golub 2001, 225-226; Gudzinevičiūtė 2006, 266-272).

The particular stylistic functions can arise from semantic transposition of gender. As Brandes argues, in German poetry nouns in masculine gender can acquire particular poetic nuance if they refer to a female person (cited from Brandes 2004, 365):

(1.102) Du warst die Königin, sie der Verbrecher (Schiller, Maria Stuart))

However, according to Gak (1999, 141), in French, grammatical masculine gender in colloquial speech expresses affinity if a masculine noun is used in addressing a woman (mon petit, mon chat). Semantic transposition of gender in Latvian is similar to French. There are a number of very popular pet names in colloquial Latvian which are formally masculine nouns or adjectives, but can be used to refer to female persons:

(1.103) dārgum-s (M) $\rightarrow$ dārgum-s (F)

mīlulis 'darling', mazulis 'baby', dārgums 'darling', saldums 'sweety', zakis 'rabbit', mazais 'baby', sīkais 'kid'

Often such nouns have the diminutive suffixes -in- and -it- with masculine endings:

(1.104) mīlul-ìt-is ‘darling’, mazul-ìt-is ‘baby’, dārgum-iṇ-š ‘darling', saldum-iñ-š 'sweety', zak-it-is 'rabbit' 
These masculine words are usually used by men to refer to women:

(1.105) Alvis. Lai redz visa pasaule,

$\begin{array}{llll}k a & \text { es } & \text { esmu } & \text { atradis } \\ \text { that I } & \text { have.COP.1SG } & \text { find.PTCP.NOM.M } \\ \text { savu } & & \text { dārgumu! } & \\ \text { my.ACC.M } & \text { darling.ACC.M } & \end{array}$

'Alvis (a young man). May everybody know that I have found my darling!'

(Zālìte)

Masculine nouns are used in colloquial style by mothers and daughters, or sometimes also by girlfriends or female friends, to refer to another female person. These masculine words function like words of the common gender in Latvian:

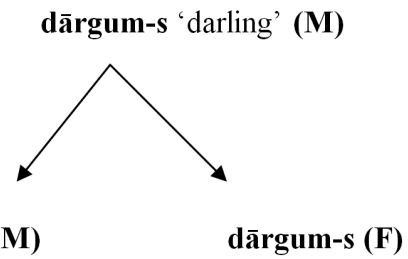

dārgum-s (M) dārgum-s (F)

Figure 1.2: Semantic transposition when masculine nouns and adjectives are related to female human beings.

Grammatical transposition of gender markers is an interesting stylistic peculiarity of Latvian. We find several widely-used feminine nouns in colloquial Latvian which function with masculine endings alongside the feminine forms (Ahero et al. 1959, 380; Smiltniece 2002, 39-40):

\section{(1.106) sieviet-e 'woman' (F) $\rightarrow$ sieviet-is (F)}

sieviet-e 'woman', meiten-e 'girl', skuk-e 'girl'

and

sieviet-is, meiten-is, skuk-is

The words sievišk-is ‘woman' and meitiet-is 'girl' which are used only with a masculine ending in Modern Latvian can be added to this group of transposed gender markers. As Wierzbicka $(1996,398)$ notes, the replacement of basic 'natural' gender by the other gender signals the speaker's expressive attitude. Usually, feminine nouns with masculine endings are used to indicate a negative or pejorative attitude. It is important to note that the 'speaker' most often is a man: 


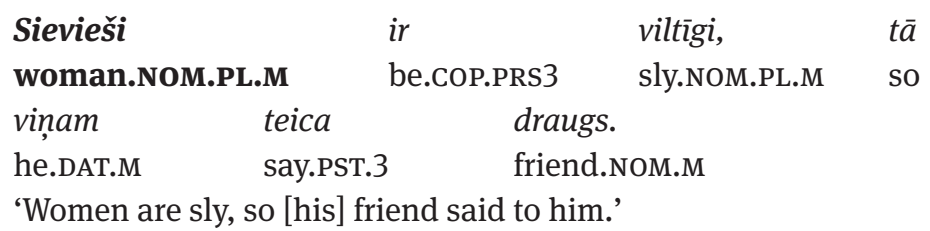

(Zigmonte)

\begin{tabular}{|c|c|c|c|c|}
\hline (1.108) & $\begin{array}{l}\text { Sievišķis } \\
\text { woman.NOM.SG.N }\end{array}$ & $\begin{array}{l}u z \\
\text { on }\end{array}$ & $\begin{array}{l}\text { jūras } \\
\text { sea.GEN.F }\end{array}$ & $\begin{array}{l}\text { vienmēr } \\
\text { always }\end{array}$ \\
\hline & $\begin{array}{l}\text { ir } \\
\text { be.AUX.PRS3 }\end{array}$ & $\begin{array}{l}\text { is } \\
\text { TCP.M }\end{array}$ & $\begin{array}{l}\text { postu. } \\
\text { disaster.ACC.M }\end{array}$ & \\
\hline
\end{tabular}

'A woman on the ship always means disaster.' (The author of the text is an old sailor.)

(Janovskis)

However, classical Latvian fiction shows that such words as sievietis 'woman', meitenis 'girl', skukis 'girl' can be used also for expressing positive or sometimes a completely neutral attitude. In this case it is important to note that the author of the text may not necessarily be a man; it can be a woman.

The word meitenis expresses a positive attitude in the following example:
(1.109) Kamēr tas [skroderis] te šuva, while that.NOM.M [costumier] here sew.PST.3 sagrozija meitenam galvu. turn.PST.3 girl.DAT.M head.ACC.F
'While this [costumier] was sewing, he also mixed up the girl's head [i.e., thinking].

(Erss)

The word sievietis used in this description of an everyday occurrence does not show a negative attitude:

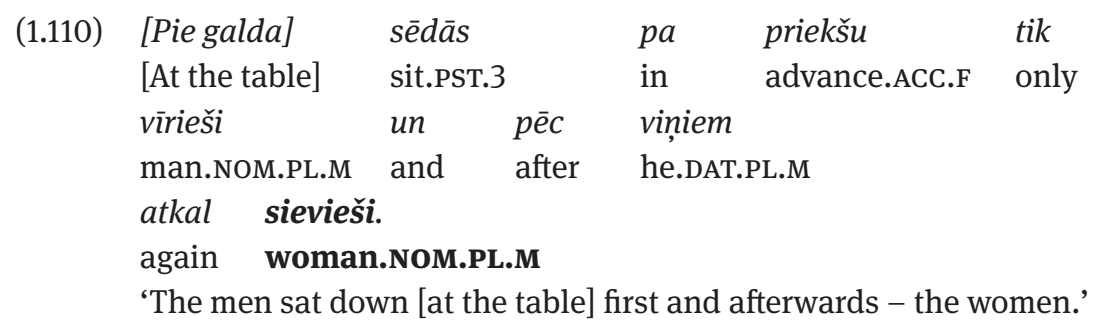

(Kaudzītes) 
Expressing the social hierarchy of a household, the word sievietis does not have a derogatory meaning:

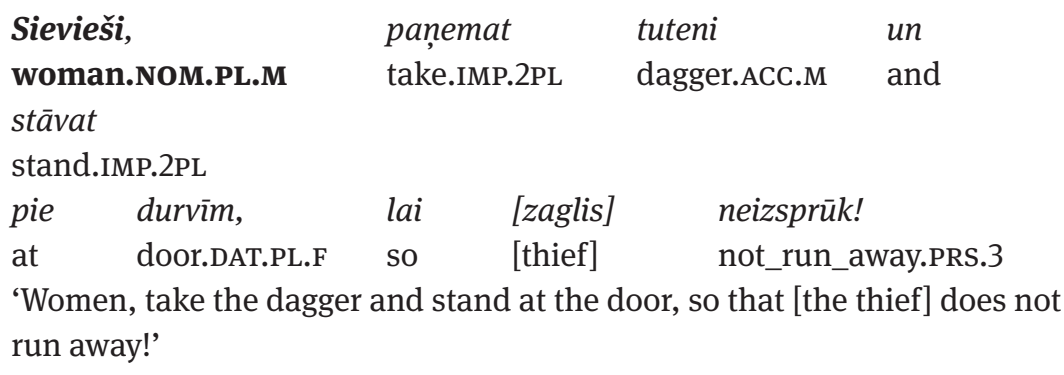

(Janševskis)

Another case of grammatical transposition of gender markers is connected with the usage of the diminutive suffixes -uk- and -èn-, which normally combine with masculine endings:

$-u k-s$ / -uc-is, -èn-s: meit-a 'daughter' (F) $\rightarrow$ meit-uk-s (F)

In colloquial Latvian, diminutives derived from feminine nouns with masculine endings are frequent, for example:

(1.112) meita 'daughter' : meit-uk-s, meit-uc-is, meit-ēn-s

mamma 'mum' : mamm-uk-s, mamm-uc-is

Ieva 'girl's name' : Iev-uk-s, Iev-uc-is, Iev-ēn-s

Ilze 'girl's name' : Ilž-uk-s, Ilz-ēn-s

In contrast to the example mentioned above, these diminutives express only a positive and friendly attitude:

\begin{tabular}{|c|c|c|c|c|}
\hline (1.113) & $\begin{array}{l}\text { Viņai } \\
\text { she.DAT.F }\end{array}$ & $\begin{array}{l}\text { bija } \\
\text { be.coP.PST.3 }\end{array}$ & $\begin{array}{l}\text { kupli } \\
\text { thick.NOM.PL.M }\end{array}$ & $\begin{array}{l}\text { mati, } \\
\text { hair.NOM.PL.M }\end{array}$ \\
\hline & $\begin{array}{l}\text { Marēns [Marija] } \\
\text { Marēns.NOM.M }\end{array}$ & $\begin{array}{l}\text { puikām } \\
\text { boy.DAT.P }\end{array}$ & $\begin{array}{l}\text { patika. } \\
\text { like.pst. }\end{array}$ & \\
\hline
\end{tabular}

'She had thick hair, and Marēns ['diminutive of Marija'] was liked by the boys.'

(Ezeriņ̌s)

It should be pointed out that such diminutives are related mainly to close family relatives and other rather intimate persons. Wierzbicka $(1996,398)$ points out in her analysis of a similar case in Polish with masculine derivations Marusik, Klarusik from the feminine nouns Maria, Klara, points out that 'the masculine gender signals an 
attitude of affectionate jocularity'. Still in standard Latvian diminutives with suffixes -in- and -it- are preferred:

(1.114) meit-iṇ-a 'darling daughter', Iev-iṇ-a 'girl's name', mamm-ït-e 'mummy', Ilz-ït-e 'girl's name'

The feminine or masculine endings added to these suffixes normally agree with the gender of the head noun.

Colloquial Latvian shows a certain dominance of the masculine gender which results from semantic and grammatical transposition of gender markers from feminine to masculine. In both cases words with masculine endings referring to female persons can express a positive, negative, or neutral attitude. Stylistic character of such words is restricted within colloquial speech, because the norms of Standard Latvian require the marking of gender deixis. Almost all terms referring to professions and different nomina agentis have parallel functions in the feminine and masculine gender demonstrating the so-called political correctness of sex (for details see Strelēvica 2004):

(1.115) skolotāj-a (F), skolotāj-s (M) 'teacher'

profesor-e $(\mathrm{F})$, profesor-s $(\mathrm{M})$ 'professor'

ärs-te (F), ārst-s (M) 'doctor'

apmeklētāj-a (F), apmeklētāj-s (M) 'visitor'

saimniec-e (F) 'landlady', saimniek-s (M) 'landlord'

However, the transpositions of gender markers, according to Foley (2001, 286-287), reflect the asymmetrical perception of gender in society where a greater prestige is granted to masculine entities. Colloquial Latvian approves of this opinion, because every change of gender markers is one-way: from feminine to masculine where female persons are described with words encoding masculine gender. Moreover, words of common gender which take feminine endings in Latvian have pejorative or negative meaning and thus they implicitly point to a lower prestige of feminine gender. However, it seems that in Modern Latvian there is no prestige attached to masculine gender nor is there discrimination encoded against female persons. The stylistic functions of gender in colloquial speech have been established historically but in present-day society they are used in this way by convention. 